110 Nordisk

Ministerråd

SKYGGEN

AF LYKKEN

De nordiske befolkninger er lykkeligere end andre i verden, men der findes også mennesker i Danmark, Finland, Island, Norge og Sverige, som giver udtryk for mistrivsel eller sågar for at være ulykkelige, når de beskriver deres liv. Denne rapport undersøger, hvem der ikke er lykkelige i Norden, samt hvilke livsomstændigheder der ligger bag. 


\section{Skyggen af lykken}

Michael Birkjær

ANP 2018:787

ISBN 978-92-893-5682-4 (PRINT)

ISBN 978-92-893-5683-1 (PDF)

ISBN 978-92-893-5684-8 (EPUB)

http://dx.doi.org/10.6027/ANP2018-787

(c) Nordisk Ministerråd 2018

Layout: Mette Agger Tang

Fotos: Unsplash.com

Tryk: Rosendahls

Printed in Denmark

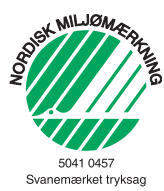

\section{Det nordiske samarbejde}

Det nordiske samarbejde er en af verdens mest omfattende regionale samarbejdsformer. Samarbejdet omfatter Danmark, Finland, Island, Norge og Sverige samt Færøerne, Grønland og Åland.

Det nordiske samarbejde er både politisk, økonomisk og kulturelt forankret, og er en vigtig medspiller i det europæiske og internationale samarbejde. Det nordiske fællesskab arbejder for et stærkt Norden i et stærkt Europa.

Det nordiske samarbejde ønsker at styrke nordiske og regionale interesser og værdier i en global omverden. Fælles værdier landene imellem er med til at styrke Nordens position som en af verdens mest innovative og konkurrencedygtige regioner.

\section{Nordisk Ministerråd \\ Nordens Hus \\ Ved Stranden 18 \\ 1061 København K \\ www.norden.org}

Download nordiske publikationer: www.norden.org/nordpub 


$$
\begin{aligned}
& \text { SKYGGEN } \\
& \text { AF LYKKEN }
\end{aligned}
$$




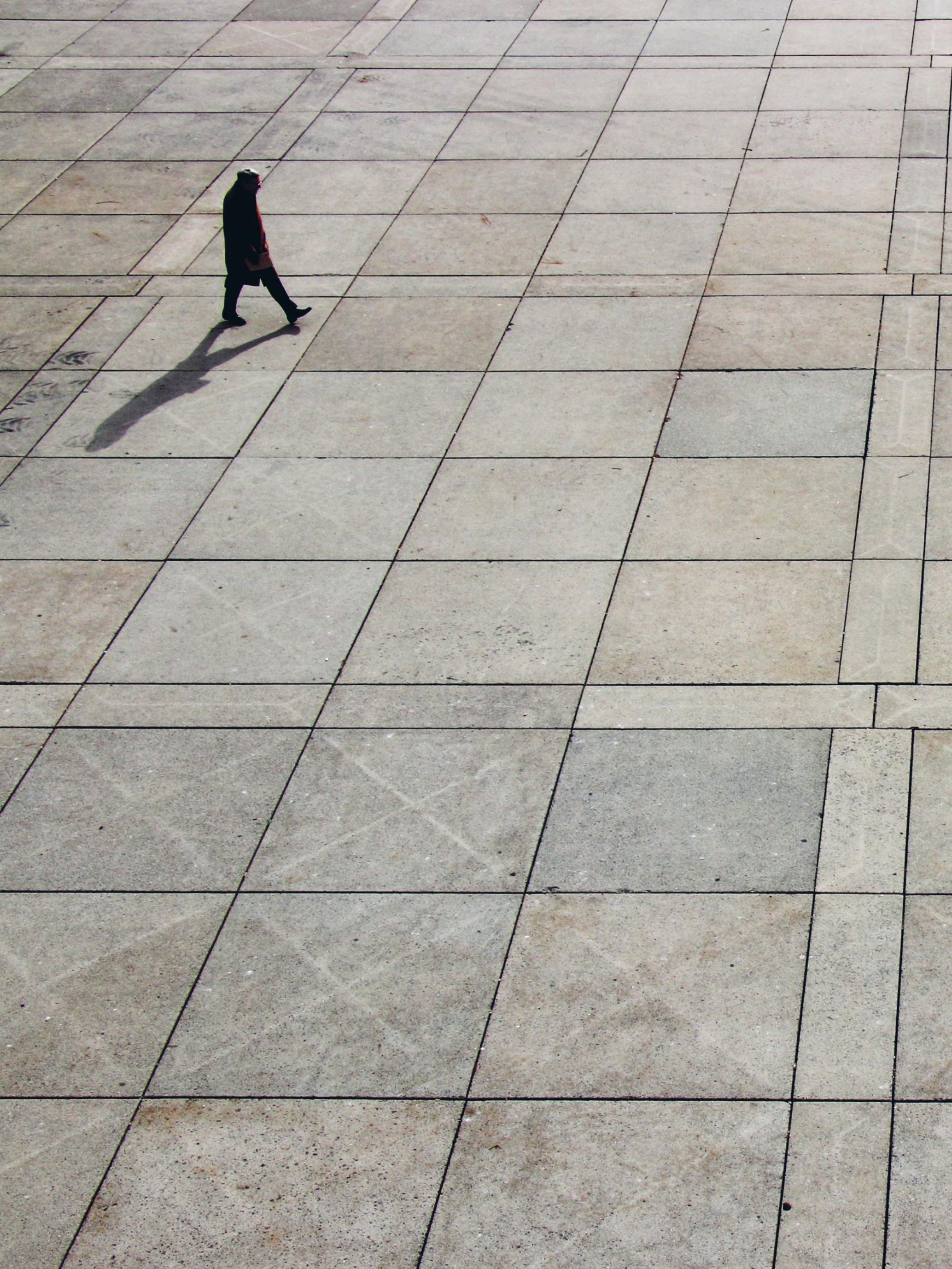




\section{Indhold}

7 Forord

8 Sammenfatning

11 Indledning

14 Det mindre lykkelige Norden

17 Ulykkens anatomi

28 Ulykkens konsekvenser

31 Nordisk perspektiv

32 Litteraturliste

34 Appendiks 1: Metode

36 Appendiks 2: Analyse

41 Appendiks 3: Sandsynligheden for depressive symptomer ved arbejdsløshed 


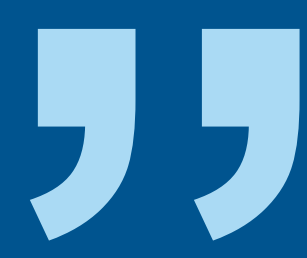

Det er af flere årsager en god idé at diskutere, hvordan man kan bidrage til, at farre mennesker mistrives eller er ulykkelige. 


\section{Forord}

Denne rapport handler om lykke i Norden. Den adskiller sig dog fra andre rapporter og artikler fra de seneste år, som nærmest enstemmigt peger på, at mennesker i Norden er lykkelige. Det er ganske vist rigtigt, at vi i denne region er lykkeligere end $\mathrm{i}$ andre regioner i verden. For langt de fleste er de nordiske lande gode at leve i. Det betyder dog ikke, at alle individer er lykkelige. Der findes også dem, der giver udtryk for mistrivsel eller sågar for at være ulykkelige, når de beskriver deres liv.

Det overordnede formål med rapporten er at give et mere nuanceret billede af "det lykkelige Norden". Hensigten er endvidere at studere, hvem der i de nordiske samfund giver udtryk for at være ulykkelige. Desuden giver rapporten et bud på årsagerne til, hvorfor lykken er så ulige fordelt.

Man har længe målt velfærd og livskvalitet ved hjælp af forskellige økonomiske indikatorer. Ikke mindst bruttonationalprodukt har været den dominerende målestok. De seneste år har andre måder at måle velfærd på tiltrukket opmærksomhed. Interessen er især blevet større for subjektive livskvalitetsindikatorer, der måler livstilfredshed og trivsel.

Det er måske ikke alene samfundets ansvar at sørge for, at alle borgere er lykkelige, men det er af flere årsager en god idé at diskutere, hvordan man kan bidrage til, at færre mennesker mistrives eller er ulykkelige.

Rapporten er hovedsageligt forfattet af Michael Birkjær ved The Happiness Research Institute på anmodning fra Nordisk Ministerråds sekretariat. Den er bearbejdet af Ulf Andreasson og Truls Stende ved ministerrådets sekretariats Analyse- og statistikenhed. Rapporten indgår i enhedens rapportserie, som skal belyse aktuelle emner, der er centrale i et nordisk perspektiv.

København, maj 2018

\section{Dagfinn Høybråten}

Generalsekretær

Nordisk Ministerråd 


\section{Sammenfatning}

Siden 2012 har både FN og OECD valgt at opgøre fremgang i trivsel, i tillæg til bruttonationalproduktet (BNP), som et mål for et lands velfærd. Undersøgelser af lykke handler om at spørge mennesker om, hvordan de har det - i stedet for at drage konklusioner på baggrund af deres indkomstniveauer.

Denne rapport handler om lykke og ulykke i Norden. Undersøgelsen viser, at vi i denne region af verden er lykkeligere end $\mathrm{i}$ andre regioner. Men der findes også dem, der giver udtryk for mistrivsel eller sågar at være ulykkelige, når de beskriver deres liv. Denne rapport undersøger, hvilke faktorer der har størst betydning for, hvorfor nogle mennesker i Norden er lykkelige, mens andre mistrives eller er ulykkelige. Vi kortlægger også, hvem der oftest mistrives eller er ulykkelige.

I de fem nordiske lande er det normalt, at man rapporterer 7, 8 og 9, når livskvaliteten evalueres på en skala fra 0 til 10. En værdi under 7 kan derfor ses som en afvigelse. I et nordisk perspektiv giver det mening at benytte følgende tre kategorier for livskvalitet:

Trivsel: Alle som scorer mellem 7 og 10

Mistrivsel: Alle som scorer mellem 5 og 6

Ulykke: Alle som scorer mellem 0 og 4

I denne rapport benyttes disse tre begrepene for at beskrive oplevet grad af lykke eller ulykke.

I analysen inkluderes almindelige demografiske variabler såsom køn og alder. Derudover testes, hvilke livsomstændigheder der er mest forbundne med ulykke og mistrivsel i de nordiske lande, såsom social kontakt, psykisk velbefindende, fysisk sundhed og beskæftigelsesstatus.

De bagvedliggende årsager til, at en person mistrives eller bliver ulykkelig, er selvsagt unikke. Dog viser resultaterne på tværs af de nordiske lande, at der er mange systematiske sammenfald og ligheder, hvilket kan indikere, at der også er nogle bestemte samfundsstrukturer, som har en negativ indvirkning på menneskers liv.

Studiets hovedkonklusioner er:

- Lykken er ulige fordelt i de nordiske lande. Rigtig mange mennesker i de nordiske lande oplever et højt niveau af trivsel, men samtidig oplever 12,3 procent af den samlede befolkning i Norden at være ulykkelige eller at mistrives.

- En betydelig andel af unge mistrives eller er ulykkelige. I aldersgruppen 18-23 år er der 13,5 procent, som mistrives eller er ulykkelige i Norden. Vi finder kun en højere andel, som mistrives eller er ulykkelige hos én anden aldersgruppe, nemlig dem over 80 år.

- Trivselsulighed i Norden er stærkt forbundet med ulighed i sundhed. Generel sundhed samt psykisk sundhed er langt tæettere forbundet med 
trivselsulighed end andre livsomstændigheder som f.eks. beskæftigelse og indkomstniveau.

- Generel sundhed er højest på den nordiske liste over livsomstændigheder som er mest forbundet med mistrivsel og ulykke. Det adskiller Norden fra USA, Australien og Storbritannien, hvor psykisk sygdom topper listen. Det er overvejende ældre mennesker i Norden, som oplever svigtende helbred.

- Psykisk sundhed er den næstvigtigste livsomstændighed for lykke og ulykke. Psykiske sundhedsproblemer rammer oftest unge, og især unge kvinder. Andelen af unge, som føler sig deprimerede, varierer mellem de nordiske lande, men det overordnede mønster er, at unge kvinder oftere føler sig ramt sammenlignet med unge mænd. En stigning i dårlig psykisk sundhed over de seneste år ses dog både hos unge kvinder og unge mænd.

- Topindkomst beskytter mod mistrivsel og ulykke. Indkomstulighed rangerer som den tredjestærkeste livsomstændighed til at forklare, hvorfor nogle mennesker er ulykkelige eller mistrives, men det er vigtigt at bemærke, at den effekt kun findes for de 10 procent af befolkningen med højest indkomst. Det vil sige, at tilhører man de 10 procent med højest indkomst, har man mindre risiko for at opleve mistrivsel eller ulykke.

- Arbejdsløshed er forbundet med mistrivsel og ulykke, især for mænd. Efter dårlig generel sundhed, dårlig psykisk sundhed og indkomstulighed følger arbejdsløshed som den mest afgørende livsomstændighed for mistrivsel og ulykke i de nordiske lande. Andelen af arbejdsløse, som er ulykkelige eller mistrives, er større end andelen af beskæftigede, som er ulykkelige eller mistrives. Det er hver tredje uden job, som ikke trives i de nordiske lande. Blandt beskæftigede er det hver tiende, som ikke trives. Trivselsproblemerne relateret til arbejdsløshed gælder især for mænd, som oftere oplever psykiske sundhedsproblemer, når de ikke er i job.

- Mangel på social kontakt er et større problem for mænd. I stort set alle aldersgrupper er mænd - og særligt ældre mænd - mindre socialt aktive, hvilket er forbundet med mistrivsel.

- Meget religiøse mennesker er mere lykkelige. I samtlige nordiske lande er meget religiøse mennesker mere lykkelige. Der ses ingen trivselsforskelle mellem ateister og moderat religiøse mennesker.

- Ulykkelige mennesker koster samfundet. Det har samfundsøkonomiske konsekvenser, at en voksende gruppe mennesker oplever ulykke og mistrivsel. Problemet er særligt relateret til sygefravær, lav produktivitet og forbruget af sundhedsydelser.

- Ulighed i trivsel udfordrer Nordens høje tillid. Mistillid er stærkt forbundet med ulighed i trivsel. Hvis trivselsuligheden vokser, kan det have store konsekvenser for tilliden mellem mennesker og samfundets sammenhængskraft. 


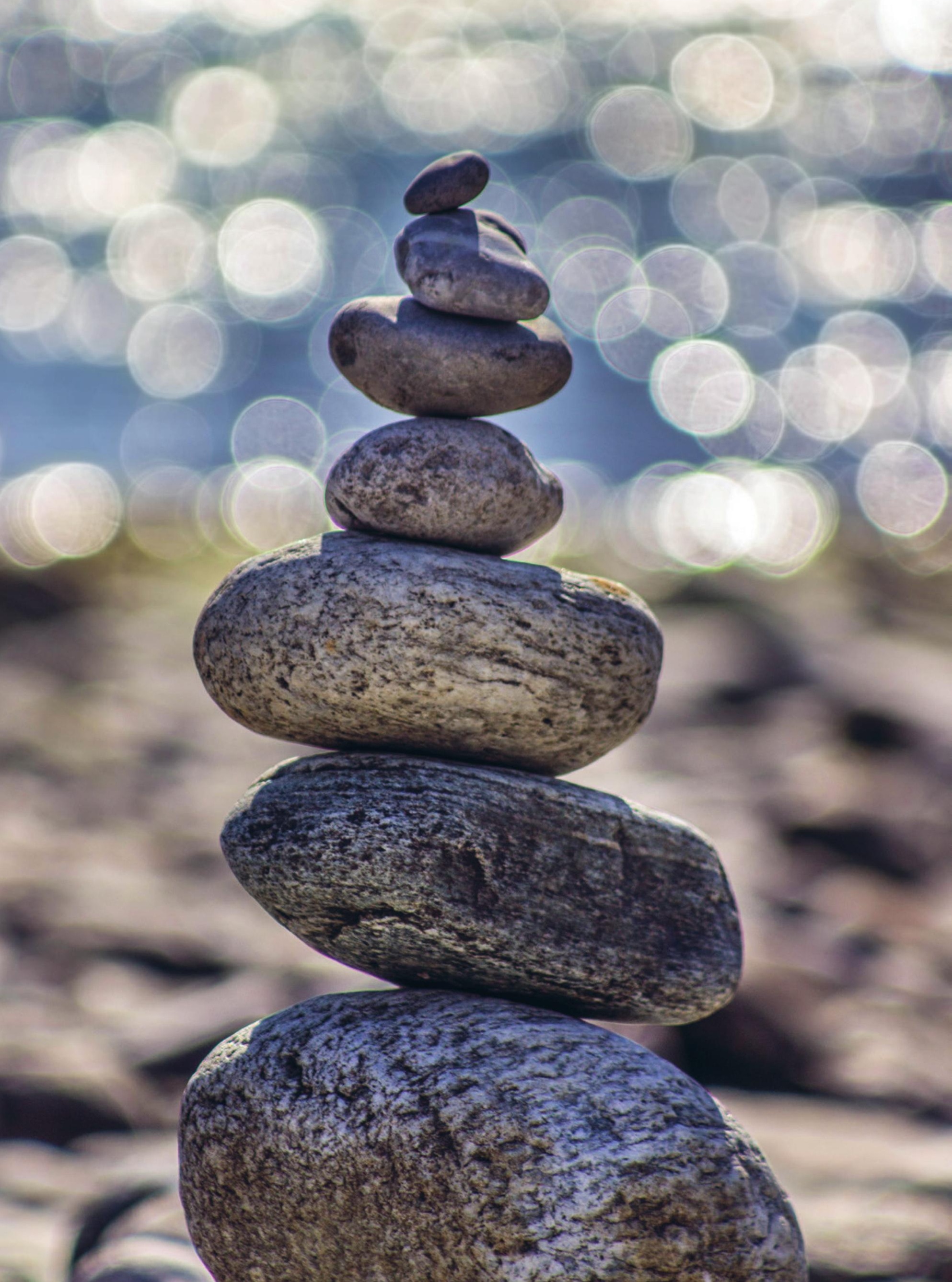




\section{Indledning}

Siden Bretton Woods-konferencen i 1944 er stigningen i et lands velfærd og udviklingsniveau blevet betragtet som lig med en stigning $i$ landets bruttonationalprodukt (BNP). Men inden for de seneste par år er der sket en nytænkning i måden, vi opgør verdens landes udviklingsniveau på: Fra 2012 har både FN og OECD valgt at bryde med den entydige økonomiske tilgang og $\mathrm{i}$ stedet valgt også at opgøre fremgang i trivsel som et mål for et lands velfærd og udviklingsniveau. Disse opgørelser bygger blandt andet på befolkningens subjektive oplevelse af lykke og livskvalitet.

FN's daværende generalsekretær, Ban Ki-Moon, har promoveret Brutto Global Lykke som målestok for vores velfærd. ${ }^{1}$ Ligeledes har OECD's generalsekretær, Àngel Gurría, påpeget, at det ultimative mål for politik bør være at øge livskvaliteten for mennesker. ${ }^{2}$

Når vi taler om - og måler - livskvalitet, benyttes ofte en række forskellige termer: Lykkemålinger, trivselsmålinger, livskvalitetsmålinger m.v. Begreberne overlapper hinanden, men kan også opfattes lidt forskelligt. At være lykkelig vil af flere nok opfattes som noget stærkere og mere emotionelt end det at have en høj livskvalitet. Det er på den måde svært at koge trivslen eller lykken ned til én ting, hvorfor lykke også kaldes et paraplybegreb. Det dækker altså over flere begreber.

I den internationale lykkeforskning er der stor konsensus om at skelne mellem tre dimensioner: ${ }^{3}$

- Livstilfredshed: Hvor lykkelig eller tilfreds man er med livet generelt.

- Affekt: Hvor lykkelig eller ulykkelig man er i øjeblikket, eller i løbet af en kortere tidsperiode.

- Eudaimonia: Hvor meningsfuld man finder tilværelsen, eller hvor meget man føler at man udnytter sit potentiale som menneske.

I denne rapport anvendes et datasæt fra European Social Survey (ESS), som har spurgt: Hvor tilfreds er du med livet? Dette er vurderet på en skala fra 0-10. Rapportens definition lægger sig derfor inden for den første af de tre kategorier - livstilfredshed - hvilket er den mest anvendte og pålidelige dimension i lykkeforskning, og den dimension som producerer flest forskningsresultater. ${ }^{4}$

I næste kapitel Det mindre lykkelige Norden, defineres begreperne trivsel, mistrivsel og ulykke, som bruges i denne rapport for at beskrive graden af oplevet trivsel og lykke.

\footnotetext{
1 UN NEWS (2012): Ban: new economic paradigm needed, including social and environmental progress

2 OECD (2017): Better Life Initiative - Measuring Well-being and progress.

http://www.oecd.org/sdd/OECD-Better-Life-Initiative.pdf

3 OECD (2013): Guidelines on Measuring Subjective Well-being

4 lbid.
}

Der er sket en forandring $\mathrm{i}$ den måde vi måler velfærd, hvor vi i højere frad også inkluderer subjektive oplevelser af lykke og livskvalitet. 
De nordiske lande er konsekvent at finde blandt de ti mest lykkelige lande i verden.

BNP påvirker det nationale lykkeniveau, men alle nordiske lande præsterer bedre trivselsmæssigt, end hvad man kunne forvente ud fra BNP-niveauerne.

\section{Norden - lykkens supermagt?}

Nordic Countries Are The Happiest In The World skriver Forbes Magazine, Can we be as happy as Scandinavians? spørger BBC, og Want to be Happy - Try moving to Finland foreslår New York Times. Det skaber overskrifter og opmærksomhed i verdenspressen, at Danmark, Finland, Island, Norge og Sverige år efter år topper ranglisterne for lykke i de mest anerkendte internationale målinger. ${ }^{5}$ I de seneste udgaver af FNs World Happiness Report, OECDs Better Life Index og Social Progress Index fra The Social Progress Imperative er de nordiske lande konsekvent at finde blandt de ti højest rangerede lande i verden. ${ }^{6}$ Se tabel 1.

De nordiske lande er samtidig nogle af verdens rigeste lande, og materiel velstand er ikke overraskende en forudsætning for trivsel. Men der er lande i verden, som er rigere end de nordiske og samtidig mindre lykkelige, som man kan se i figur 1. Figuren viser sammenhængen mellem BNP per indbygger og lykkeniveau. Den røde trendlinje viser den gennemsnitlige sammenhæng, og dermed er de lande, der ligger over linjen mere lykkeligere, end hvad deres BNP-niveau forudsiger. De nordiske lande er altså gode til at konvertere velstand til livskvalitet i sammenligning med resten af verden. Tallene er baseret på det seneste års data.

Som det fremgår i figur 1 , ligger de nordiske lande alle over den stiplede røde linje, som markerer den forventede sammenhæng mellem lykkeniveauet og BNP per indbygger. I 2018 ligger Finland for første gang nummer ét på listen i FN's World Happiness Report over verdens lykkeligste lande, på trods af at Finlands BNP ligger væsentligt under BNP-niveauet for de øvrige nordiske lande samt eksempelvis Tysklands og USAs. Faktisk præsterer alle de nordiske lande bedre rent trivselsmæssigt, end hvad man kunne forvente alene ud fra deres BNP-niveauer.

Der er meget begrænsede gevinster at høste på trivselsniveauet i de andre nordiske lande, hvis man udelukkende fokuserer på økonomisk vækst målt i BNP (se appendiks 2, punkt A). I Norge ville det for eksempel kræve en BNPvækst på 70 procent for at løfte trivselsniveavet med 5 procent, såfremt økonomisk vækst målt i BNP var det eneste værktøj, man kunne benytte sig af.

Hvordan kan det være, at befolkningerne i de nordiske lande er så lykkelige? Undersøgelser viser, at det i høj grad skyldes den nordiske models evne til at skabe gode rammer for gode liv: Et socialt sikkerhedsnet som skaber tryghed, gratis uddannelse der giver frihed og muligheder, og en fornuftig balance mellem arbejde og fritid som giver mulighed for at nyde både arbejdsliv og familieliv. 8
Undersøgelser viser, at den nordiske lykke kan forklares med et socialt sikkerhedsnet, gratis uddannelse og en fornuftig balance mellem arbejde og fritid.

\footnotetext{
5 De nordiske lande topper ranglister som spørger til en respondents egen subjektive evaluering af hendes/hans overordnede tilfredshed med livet. I målinger af affektiv lykke en kortvarig følelsesmæssig tilstand - ligger de nordiske lande typisk lavere end for eksempel de latinamerikanske lande. Se for eksempel Gallup (2017) Global Emotion Report

6 Både World Happiness Report og OECD Better Life Index baserer sine rangeringer på subjektive livskvalitetsmålinger. Social Progress Index er derimod en indeksering, som er sammensat af mere objektive mål såsom adgang til uddannelse, gennemsnitlig levealder, sundhed m.v.

7 Udregningen er baseret på online-tilgængelig data fra World Happiness Report 2018 og økonomiske 2017-nøgletal fra IMF
} 
På trods af at vi i de nordiske lande konsekvent topper internationale målinger af trivsel og livstilfredshed, så oplever mange danskere, finner, islændinge, nordmænd og svenskere alligevel mistrivsel eller ulykke (altså det modsatte af lykke). Ambitionen med denne rapport at belyse uligheden i trivsel i Norden, at grave et spadestik dybere end de internationale lykkeranglister baseret på gennemsnitsberegninger og at forsøge at sætte et ansigt på de personer, der er i bunden af trivselsfordelingen. Hvem er de ulykkelige? Hvilke livsomstændigheder er forbundet med ulykke? Og hvad er samfundskonsekvenserne af mistrivsel og ulykke?

\begin{tabular}{|l|c|c|}
\hline \multicolumn{1}{|c|}{$\mathbf{2 0 1 8}$} & $\begin{array}{c}\text { OECD - Better Life } \\
\text { Index } 2018\end{array}$ & $\begin{array}{c}\text { Social Progress Index } \\
2017\end{array}$ \\
\hline Finland & Norge & Danmark \\
\hline Norge & Danmark & Finland \\
\hline Danmark & Australien & Island \\
\hline Island & Sverige & Norge \\
\hline Schweiz & Canada & Schweiz \\
\hline Holland & Schweiz & Canada \\
\hline Canada & Island & Holland \\
\hline New Zealand & USA & Australien \\
\hline Sverige & Finland & New Zealand \\
\hline Australien & Holland & \\
\hline
\end{tabular}

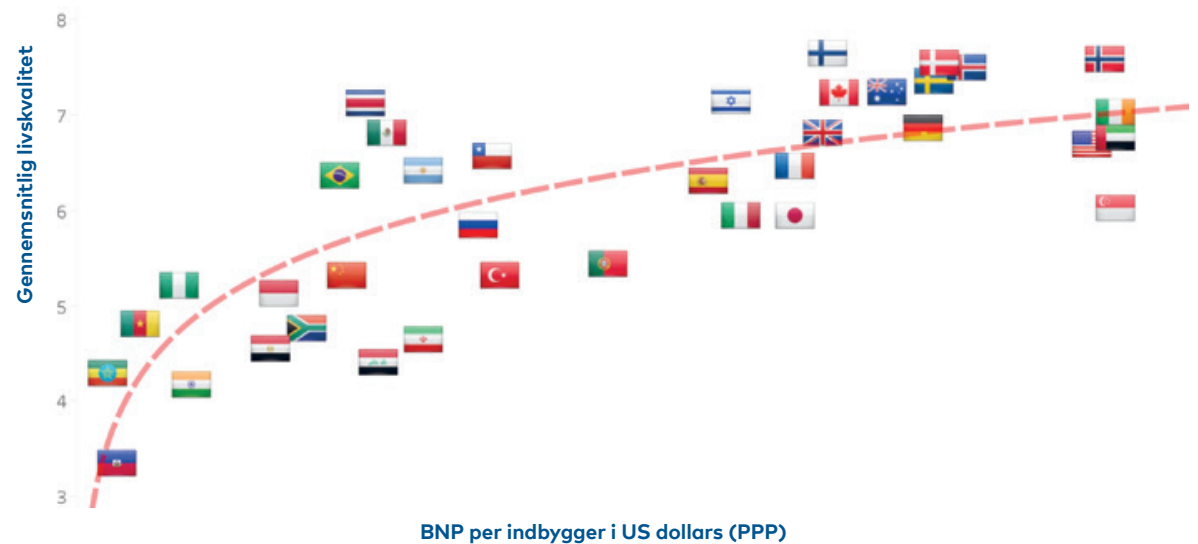

Tabel 1

Top 10, World Happiness Report, Better Life Index og Social Progress Index
Figur 1

Sammenhæng mellem BNP og trivselsniveau, 2017

Kilde: The Happiness Research Institute baseret på livskvalitetsdata fra Gallup World Poll og økonomiske nøgletal fra IMF. 


\section{Det mindre lykkelige Norden}

Det stigende fokus på trivsel og lykke i den vestlige verden har øget behovet for mere nuancerede metoder at måle et lands udvikling på. Det har blandt andet resulteret i, at OECD i 2012 lancerede Better Life Index, samme år som FN udgav den første World Happiness Report.

Både World Happiness Report og Better Life Index rangerer befolkningers trivsel baseret på nationale gennemsnit. Den gennemsnitlige trivsel fortæller os noget om det samlede trivselsniveau $i$ et land, men det giver os ikke indblik $i$, hvordan trivslen er fordelt.

Der findes ikke én fælles anerkendt standard for måling af trivselsulighed. Det skyldes blandt andet, at forskningen i mistrivsel først for nylig har fået opmærksomhed. Det skyldes muligvis også, at trivselsulighed er et lidt mere komplekst begreb end gennemsnitlig lykke.

12,3 procent af befolkningen i Norden oplever mistrivsel eller ulykke. Størst andel findes i Sverige og mindst i Danmark. Uligheden er tiltagende i Danmark og Sverige og aftagende i Finland, Island og Norge.
I 2016 blev World Happiness Report den første rapport, der præsenterede et globalt indeks over landes trivselsulighed. Den viste blandt andet, at uligheden $\mathrm{i}$ trivsel er tiltagende i Danmark og Sverige, men aftagende i Finland og Norge og er blevet betydeligt mindre i Island.

I denne rapport forholder vi os til ulighed $\mathrm{i}$ trivsel ved at analysere "proportioner" (se appendiks 1 ). I de fem nordiske lande er det normalt, at man rapporterer 7, 8 og 9, når livskvaliteten evalueres på en skala fra 0-10. Derfor betragtes en værdi under 7 som en afvigelse. Med dette in mente finder vi det meningsfuldt i et nordisk perspektiv at benytte de følgende tre kategorier for livskvalitet:

Trivsel: Alle som scorer mellem 7 og 10

Mistrivsel: Alle som scorer mellem 5 og 6

Ulykke: Alle som scorer mellem 0 og 4

Denne opdeling af kategorier anvendes også for flere andre lande af f.eks. Gallup World Poll, som definerer de tre grupper som hhv. thriving, struggling og suffering. ${ }^{9}$

Som tabel 2 viser, er ulykke og mistrivsel i Norden ikke ligeså udbredt som i f.eks. Frankrig, Storbritannien, Tyskland og især Rusland, hvor over halvdelen af befolkningen mistrives eller er ulykkelige.

Selvom mistrivsel og ulykke ikke er ligeså udbredt i Norden som i andre lande, så bør det ikke ignoreres. Det er en betydelig andel, når 12,3 procent af befolkningen i Norden ikke trives (dette er den samlede andel som oplever mistrivsel og ulykke). Tallenere varierer fra Danmark, hvor omkring 8 procent oplever ulykke eller mistrivsel, til Sverige hvor der er næsten dobbelt så stor andel næsten 15 procent. Lægger man hertil, at en stor andel unge er ulykkelige eller mistrives, er der yderligere grund til bekymring. Det kigger vi nærmere på i det følgende kapitel.

9 Gallup (tilgået april, 2018): Understanding How Gallup uses the Cantril Scale 


\begin{tabular}{|l|c|c|c|}
\hline \multirow{2}{*}{ Hele Norden } & Ulyke (0-4) & Mistrivsel (5-6) & Trivsel (7-10) \\
\hline Danmark & $3,9 \%$ & $8,4 \%$ & $87,7 \%$ \\
\hline Finland & $3,0 \%$ & $5,1 \%$ & $91,9 \%$ \\
\hline Island & $3,6 \%$ & $7,9 \%$ & $88,5 \%$ \\
\hline Norge & $4,1 \%$ & $8,5 \%$ & $87,3 \%$ \\
\hline Sverige & $3,9 \%$ & $9,3 \%$ & $86,8 \%$ \\
\hline Holland & $4,6 \%$ & $10,3 \%$ & $85,1 \%$ \\
\hline Schweiz & $4,3 \%$ & $8,0 \%$ & $87,7 \%$ \\
\hline Tyskland & $4,7 \%$ & $8,3 \%$ & $87,0 \%$ \\
\hline Storbritannien & $8,3 \%$ & $14,2 \%$ & $77,5 \%$ \\
\hline Frankrig & $9,6 \%$ & $15,5 \%$ & $74,9 \%$ \\
\hline Rusland & $17,0 \%$ & $23,4 \%$ & $59,6 \%$ \\
\hline
\end{tabular}

Tabel 2

Fordeling af ulykke, mistrivsel og trivsel, 2012-2016

Kilde: The Happiness Research Institute på baggrund af data fra European Social Survey. 


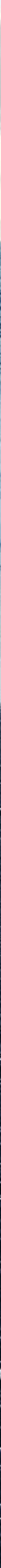




\section{Ulykkens anatomi}

I dette kapitel ser vi på, hvilke faktorer der har størst betydning for, hvorfor nogle mennesker i Norden er lykkelige, mens andre mistrives eller er ulykkelige. Vi kortlægger også, hvem der oftest oplever mistrivsel og ulykke, og forholder os til forskelle på tværs af køn, alder og beskæftigelsesstatus.

For at besvare spørgsmålet om, hvilke livsomstændigheder der har størst betydning for ulykke og mistrivsel i de nordiske lande, har vi gennemført en regressionsanalyse. I denne analyse inkluderer vi almindelige demografiske variabler, og derudover ønsker vi at teste områder, som ofte fremhæves i forskningen som faktorer, der påvirker trivsel. Det er blandt andet social kontakt, psykisk sundhed, fysisk sundhed og beskæftigelsesstatus. For mere information, se appendiks 2, punkt B.

Det er vigtigt at bemærke, at de sammenhænge, vi finder mellem mistrivsel, ulykke og livsomstændigheder, ikke kan afgøre en bestemt kausalitet: Det vil sige, at vi ikke kan afgøre, om det for eksempel er dårligt fysisk helbred, som forårsager mistrivsel og ulykke, eller om det omvendt er mistrivsel og ulykke, der forårsager dårligt fysisk helbred. Vi kan kun identificere, at der er en sammenhæng mellem disse faktorer.

I mange tilfælde vil man antage, at der er en effekt, som går begge veje. I forholdet mellem sygdom og ulykke, giver det for eksempel intuitivt mening, at et voldsomt sygdomsforløb forårsager ulykke for den pågældende. De seneste år findes der dog også stigende bevis for en omvendt kausalitet: Vi ser for eksempel, at lykkelige mennesker lever længere, ${ }^{10}$ og at helbredet påvirkes negativt af dårlig trivsel gennem stresshormoner og kronisk inflammation. ${ }^{11}$ For at forstå de præcise sammenhænge mellem livsomstændigheder og trivsel, kræves yderligere forskning.

\section{Hvor er mistrivslen og ulykken mest udbredt?}

Før vi ser på, hvilke livsomstændigheder der er mest forbundet med mistrivsel og ulykke, præsenterer vi her et overblik over, hvor mistrivsel og ulykke er mest udbredt. Vi forholder os her til variationer mellem lande, alder og køn.

Det er et udbredt mønster inden for lykkeforskning globalt, at et menneskes trivsel og livskvalitet målt over et helt liv tegner sig grafisk som en U-form. ${ }^{12}$ Det vil sige, at ungdommen er den lykkeligste tid, derefter oplever mange mennesker en midtvejskrise, indtil trivslen igen stiger, efterhånden som vi bevæger os ind i alderdommen.
Det kan være svært at afgøre, hvad der forårsager mistrivsel og ulykke, og hvad der er en konsekvens. Vi kan kun identificere, at der er en sammenhæng mellem faktorer.

\footnotetext{
10 Steptoe, A. Et al. (2011): Positive affect measured using ecological momentary assessment and survival in older men and women

11 What Works Well-Being (2017): Measuring Well-Being Inequalities: A How-To Guide

12 Helliwell et al. (2015): World Happiness Report 2015
} 
I aldersgruppen 18-23 år angiver 13,5 procent mistrivsel og ulykke. Kun aldersgruppen over 80 år er mere udsatte.
De livsomstændigheder, som er mest forbundet med ulykke og mistrivsel er dårligt generelt helbred, dårlig psykisk sundhed, indkomstulighed, arbejdsløshed og begrænset social kontakt.
Dette mønster ser vi dog udfordret i dag, og forklaringen skal blandt andetfindes i de unges lykkeniveau, se figur 2.

Figur 2 viser, at 13,5 procent af unge i aldersgruppen 18-23 år i Norden hører til kategorierne mistrivsel og ulykke. Det gør denne aldersgruppe til den mest udsatte næst efter personer over 80 år.

Unge kvinder mistrives oftere end unge mænd, se figur 3. Figuren viser, at det står værst til i Sverige, hvor 6,5 procent af unge kvinder er ulykkelige, mens 13 procent mistrives. Det er samlet set 19,5 procent - altså næsten hver femte unge kvinde. Blandt unge svenske mænd er tallene hhv. 3,1 procent for ulykke og 10,7 procent for mistrivsel. Den mest markante kønsforskel findes i Island, hvor flere end tre gange så mange unge kvinder er ulykkelige sammenlignet med unge mænd. Det eneste land der ikke passer ind i det mønster, er Danmark. Her er der stadig flere unge kvinder end unge mænd, som er ulykkelige (3,3 procent i forhold til 2,4 procent af de unge mænd), men der er betydeligt færre unge kvinder (2,7 procent) end unge mænd (7,1 procent), der mistrives.

I vores analyse finder vi også en række relevante resultater, som vi ikke kommer nærmere ind på i denne rapport:

- $\quad$ Der er ingen forskel på, hvor lykkelige folk er i byerne og på landet.

- Pensionister i Norden har mindre risiko for mistrivsel end personer på arbejdsmarkedet.

- Mennesker i Norden, der bor sammen med en partner, har mindre risiko for mistrivsel.

- Etniske minoriteter er mindre lykkelige end majoritetsbefolkningen.

\section{Livsomstændigheder som er mest forbundet med mistrivsel og ulykke}

Når alle variablerne (livsomstændigheder) testes i forhold til deres forklaringskraft på mistrivsel og ulykke, finder vi en række betydelige sammenhænge. Livsomstændigheder såsom dårlig generel sundhed, dårlig psykisk sundhed, indkomstulighed, arbejdsløshed, begrænset social kontakt og religiøsitet spiller alle sammen en rolle. Nogle faktorer er dog langt mere betydningsfulde end andre. I tabel 3 har vi rangordnet de livsomstændigheder, som er mest forbundne med mistrivsel og ulykke i Norden.

Tabel 3 viser, at de livsomstændigheder som er mest forbundne med mistrivsel og ulykke, er dårlig generel sundhed og derefter dårlig psykisk sundhed. En uddybning af de nordiske tal og tilhørende analyse findes i appendiks 2, punkt C.

I tabel 4 på side 21 vises rangordninger for vigtige livsomstændigheder i andre lande (USA, Australien, Storbritannien og lavindkomstlande), hvor andre undersøgelser ${ }^{13}$ har anvendt samme metode, som vi anvender i denne rapport. Det fremgår af tabellen, at psykiske sundhedsproblemer - på samme måde som i Norden - er en af de livsomstændigheder, der er stærkest forbundet med mistrivsel og ulykke i mange andre lande.

13 The Global Happiness Council (2018): Global Happiness Policy 

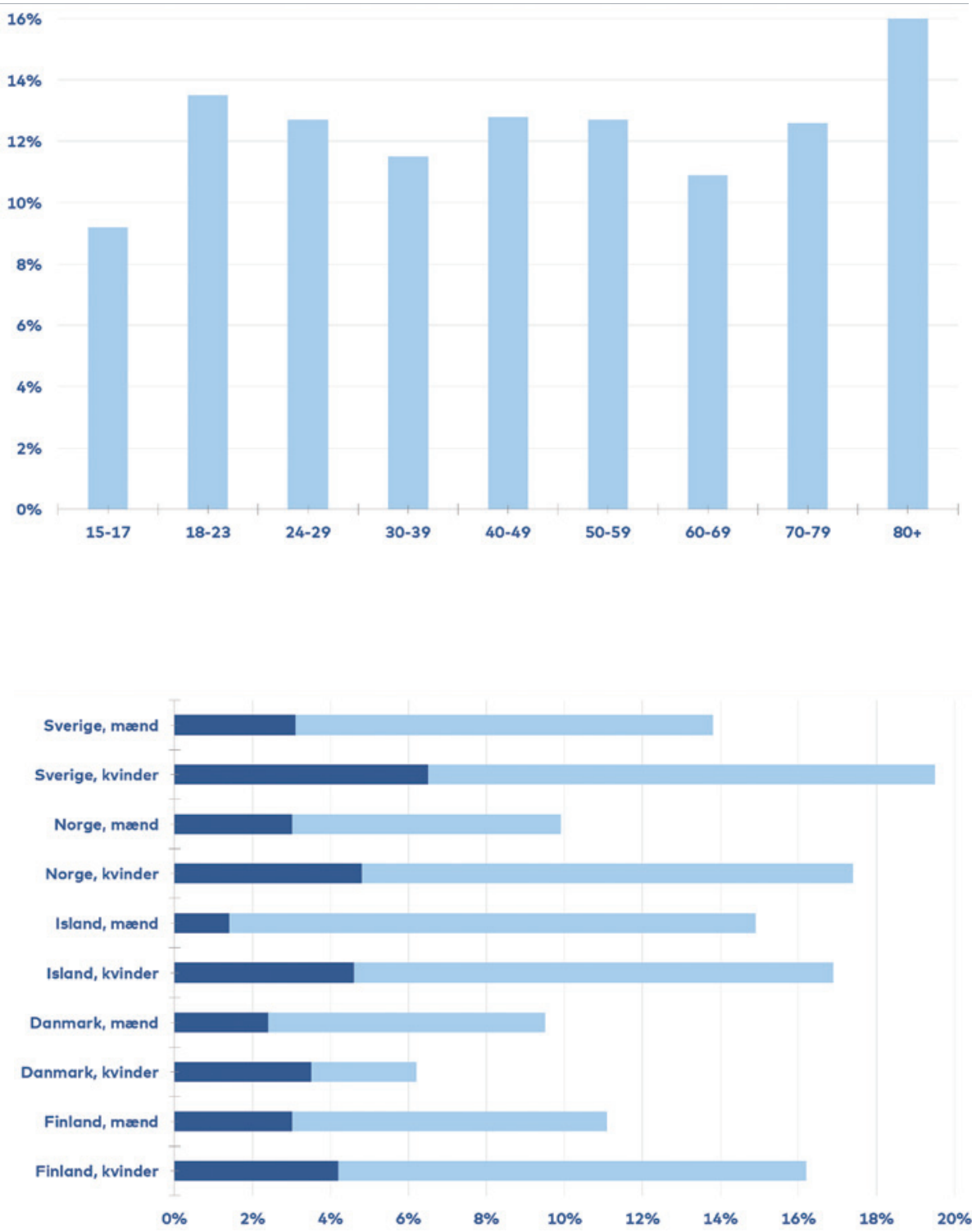

\begin{tabular}{|l|l|}
\hline \multicolumn{1}{|l|}{} & Top-5 i Norden \\
\hline 1 & Dårlig generel sundhed \\
\hline 3 & Dårlig psykisk sundhed \\
\hline 4 & Indkomstulighed \\
\hline 5 & Arbejdsløshed \\
\hline
\end{tabular}

Figur 2

Andel som er ulykkelig

eller mistrives $i$

Norden (på tværs af aldersgrupper), 20122016

Kilde: The Happiness Research Institute på baggrund af data fra European Social Survey.

Figur 3

Andel unge (18-23) som er ulykkelige eller mistrives i de nordiske lande (på tværs af køn), 2012-2016

Kilde: The Happiness Research Institute på baggrund af data fra European Social Survey.

Ulykke

Mistrivsel
Tabel 3

Livsomstændigheder som er mest forbundet med ulykke og mistrivsel, 2012-2016

Kilde: The Happiness Research Institute. 
Kvinder rapporterer oftere dårligere helbred end mænd, særligt i Danmark, Norge og Sverige.

\section{Sundhed splitter Norden - mere end noget andet}

På tværs af alle nordiske lande er ulighed i generel sundhed og psykisk sundhed de mest afgørende faktorer for, hvorfor nogle mennesker trives, og andre mistrives eller er ulykkelige. Med generel sundhed menes ikke psykisk sundhed.

I forhold til den generelle sundhed er det - måske ikke så overraskende - den ældre del af befolkningen i de nordiske lande, som oftest føler, at helbredet svigter. Der findes dog nogle ret interessante forskelle mellem landene. I Finland er der således flere ældre, som rapporterer at have dårligt helbred sammenlignet med de øvrige nordiske lande, se figur 4. 9,5 procent af finnerne i aldersgruppen 70-79 rapporter at have dårligt helbred, og for den ældste gruppe (80+) er andelen 15,1 procent. Til sammenligning er tallene i Norge henholdsvis 7,5 procent og 11,4 procent, og i Danmark henholdsvis 4,4 procent og 10,6 procent.

Mens Finland har flere ældre som rapporterer dårligt helbred sammenlignet med de øvrige nordiske lande, så gør det modsatte sig gældende for de øvrige aldersgrupper: Andelen af finner i alderen 15 og helt op til 59, som rapporterer dårligt helbred, er lavere end i de øvrige nordiske lande: For eksempel er det kun 0,5 procent af de yngste (15-17), som rapporter dårligt helbred i Finland, mens tallene varierer mellem 1,9 procent og 2,8 procent i de andre nordiske lande.

En anden interessant observation er, at kvinder oftere rapporterer dårligt helbred end mænd (se figur 5). Dette gør sig særligt gældende i Danmark, Norge og Sverige, dog er forskellen relativt lille i Island. I Finland er der ingen forskel. Der er en påfaldende voverensstemmelse mellem disse tal og tal for gennemsnitlig levealder. Mænd i Norden rapporterer generelt bedre helbred, men alligevel er mænds levealder væsentligt lavere end kvinders. ${ }^{14}$ Forklaringen på dette paradoks er kompleks og kan findes i faktorer som biologi, livsstil og brug af sundhedsvæsenet. ${ }^{15}$

At generelle sundhedsproblemer er så stærkt forbundne med ulykke og mistrivsel i Norden, kommer ikke som en overraskelse. Et tidligere internationalt studie har blandt andet vist, at en kronisk sygdom som psoriasis påvirker menneskers livskvalitet mere i de generelt lykkelige lande, såsom Danmark og Norge, end i mindre lykkelige lande, såsom Rusland og Brasilien. ${ }^{16}$ Der findes flere hypoteser om, hvorfor dette gør sig gældende, men en gængs forklaring er, at bekymringer om vold, kriminalitet og risiko for fattigdom er begrænsede i de nordiske samfund, hvorfor bekymringer relateret til sygdomme ender med at fylde mere i folks bevidsthed og derfor også får en større negativ effekt på trivslen. ${ }^{17}$

Resultaterne relateret til psykisk sundhed stemmer overens med resultater fra internationale studier. I Global Happiness Policy Report 2018 har forfatterne samlet data fra alle verdens lande og estimeret, hvilke livsomstændigheder der skaber mest ulykke blandt mennesker. Rapporten konkluderer, at selv i lande, hvor indkomstuligheden er markant større end i de nordiske lande -

\footnotetext{
Nordisk Samarbejde (tilgået maj, 2018): Forventet Levealder

15 Statens Institut for Folkesundhed (2007): Folkesundshedsrapporten

6 Happiness Research Institute \& Leo Innovation Lab (2017): World Psoriasis Happiness Report

7 Ibid.
} 


\begin{tabular}{|l|l|l|l|l|}
\hline 1 & USA & Australien & Storbritannien & $\begin{array}{l}\text { Lavindkomst- } \\
\text { lande }\end{array}$ \\
\hline $\mathbf{2}$ & $\begin{array}{l}\text { Dårlig psykisk } \\
\text { sundhed }\end{array}$ & $\begin{array}{l}\text { Dårlig psykisk } \\
\text { sundhed }\end{array}$ & $\begin{array}{l}\text { Dårlig psykisk } \\
\text { sundhed }\end{array}$ & $\begin{array}{l}\text { Indkomst- } \\
\text { ulighed }\end{array}$ \\
\hline 3 & ulighed & $\begin{array}{l}\text { Dårlig generel } \\
\text { sundhed }\end{array}$ & $\begin{array}{l}\text { Dårlig generel } \\
\text { sundhed }\end{array}$ & $\begin{array}{l}\text { Dårlig psykisk } \\
\text { sundhed }\end{array}$ \\
\hline 4 & $\begin{array}{l}\text { Dårlig generel } \\
\text { sundhed }\end{array}$ & $\begin{array}{l}\text { Andkomst- } \\
\text { ulighed }\end{array}$ & $\begin{array}{l}\text { Indkomst- } \\
\text { ulighed }\end{array}$ & $\begin{array}{l}\text { Dårlig generel } \\
\text { sundhed }\end{array}$ \\
\hline
\end{tabular}

Tabel 4

Top 4 relevante livsomstændigheder globalt

Kilde: The Global Happiness Council (2018): Global Happiness Policy.

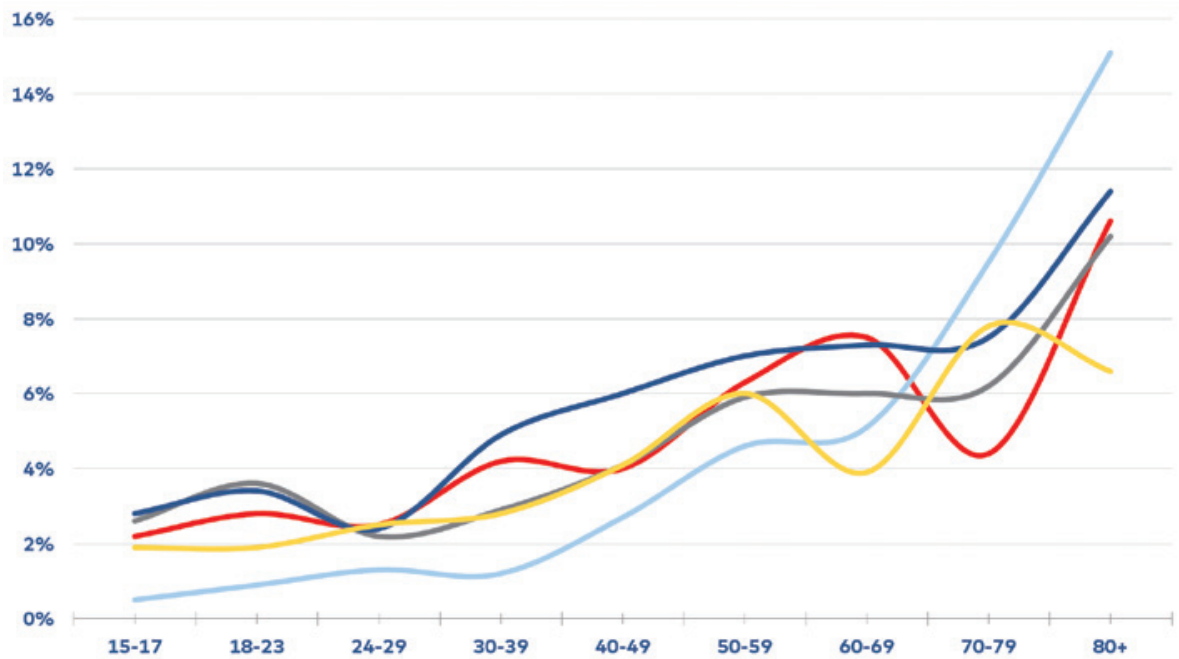

Figur 4

Andel som rapporterer dårligt eller meget dårligt generelt helbred (på tværs af lande og aldersgrupper), 20122016

Kilde: The Happiness Research Institute på baggrund af data fra European Social Survey.

Danmark

Finland

Island

- Norge

Sverige

Figur 5

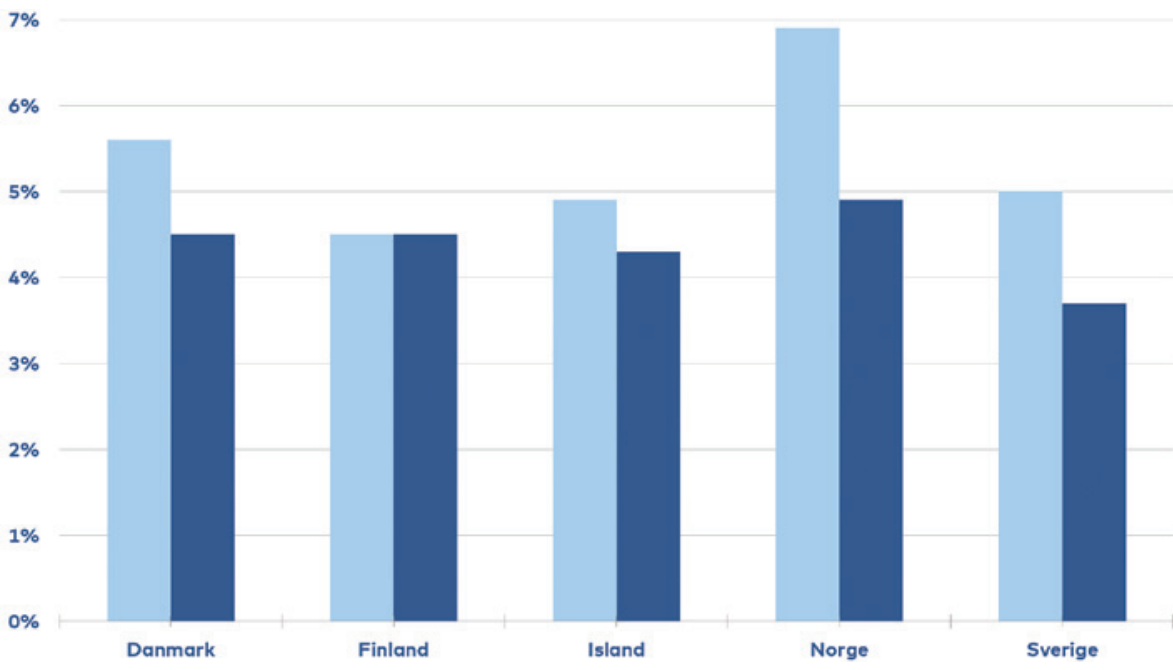

Andel af mænd og kvinder som oplever dårligt eller meget dårligt generelt helbred, 2012-2016

The Happiness Research Institute på baggrund af data fra European Social Survey.

Mænd

Kvinder 
Unges psykiske sundhed i Norden er generelt faldende. Det manifesterer sig i stress, depression, angst, selvskade, forbrug af antidrepressiv medicin og i yderste tilfælde selvmord.

Den faktor, som på et globalt plan bedst forklarer forskellen mellem lykkelige og ulykkelige befolkninger, er indkomst.

De allerrigeste rammes sjældent af mistrivsel og ulykke. såsom USA, Australien og Storbritannien - er psykiske sundhedsproblemer den mest afgørende faktor for, om man trives eller ej. Kun i lavindkomstlande har indkomstulighed en større effekt, men her er psykisk sundhed stadig den næstmest afgørende livsomstændighed. ${ }^{18}$

Den psykiske sundhed blandt unge i Norden er generelt forværret. ${ }^{19}$ I Norge ser vi for eksempel over en femårig periode en stigning på 40 procent i andelen af unge, som søger hjælp til psykiske problemer. ${ }^{20}$ I Danmark lever 18,3 procent af unge mellem 16 og 24 år med dårligt psykisk helbred. Tallet er et gennemsnit af de 12,9 procent for mænd og hele 23,8 procent for kvinder. ${ }^{21}$

De psykiske sundhedsproblemer blandt unge manifesterer sig i både stress, depression, angst, selvskade, forbrug af antidepressiv medicin og i yderste tilfælde selvmord. Sidstnævnte er et særligt stort problem i Finland, der ellers rangerer som det lykkeligste land ifølge World Happiness Report i 2018. Hér er selvmord årsag til en tredjedel af alle dødsfald blandt 15-24-årige. ${ }^{22}$

I forhold til depressive symptomer finder vi i denne undersøgelse en meget markant kønsforskel: Island har den højeste andel af unge kvinder, som føler sig deprimerede (9,2 procent), mens den er lavest i Danmark (6 procent). Se figur 6. For unge mænd er tallene konsekvent lavere og varierer mellem 0,8 procent i Norge og 3,9 procent i Sverige. Se figur 7.

\section{Kun topindkomst beskytter mod ulykke}

På et globalt plan er indkomst den faktor, som bedst forklarer forskellen mellem lykkelige og ulykkelige befolkninger, ${ }^{23}$ men i de nordiske lande er indkomstforskellene ikke ligeså afgørende for menneskers trivsel. Indkomstulighed rangerer som den tredje stærkeste livsomstændighed, der kan forklare, hvorfor nogle mennesker er ulykkelige eller mistrives. Men det er vigtigt at bemærke, at den effekt kun eksisterer for de 10 procent af befolkningen med den højeste indkomst. Dvs. tilhører man de 10 procent med den højeste indkomst, har man mindre risiko for at opleve mistrivsel eller ulykke. Dog findes ingen signifikant forskel på, om personer, der mistrives eller er ulykkelige, har en indkomst i f.eks. de laveste 10 procent eller nær middelindkomsten. Vi kan altså ikke konkludere, at des højere indkomst man har, desto mindre ulykkelig er man. Vi kan kun sige, at de allerrigeste sjældent rammes af mistrivsel eller ulykke.

Indkomstulighed er imidlertid stærkt forbundet med ulighed i sundhed. Der findes markante sundhedsforskelle mellem mennesker med en lav-, middel- og topindkomst; idet der både er en højere dødelighed og en større sygdomsfrekvens blandt fattige. ${ }^{24}$ I Norge og Finland er den type social ulighed yderligere påvirket af, at mennesker med en højere indkomst i højere grad benytter sig af sundhedsservices. ${ }^{25}$

\footnotetext{
18 The Global Happiness Council (2018): Global Happiness Policy Report

19 The Global Happiness Council (2018): Global Happiness Policy Report

20 Reneflot, A. et al. (2018): Psykisk Helse i Norge

21 SDU (2017): Den Danske Sundhedsprofilundersøgelse

22 Nordic Council of Ministers, Nordic Centre for Welfare and Social Issues (2016): Mental health among youth in Finland: Who is responsible? What is being done?

23 Helliwell et al. (2018): World Happiness Report 2018

24 Nordic Council of Ministers, Nordregio (2018): State of the Nordic Region 2018

25 Ibid.
} 


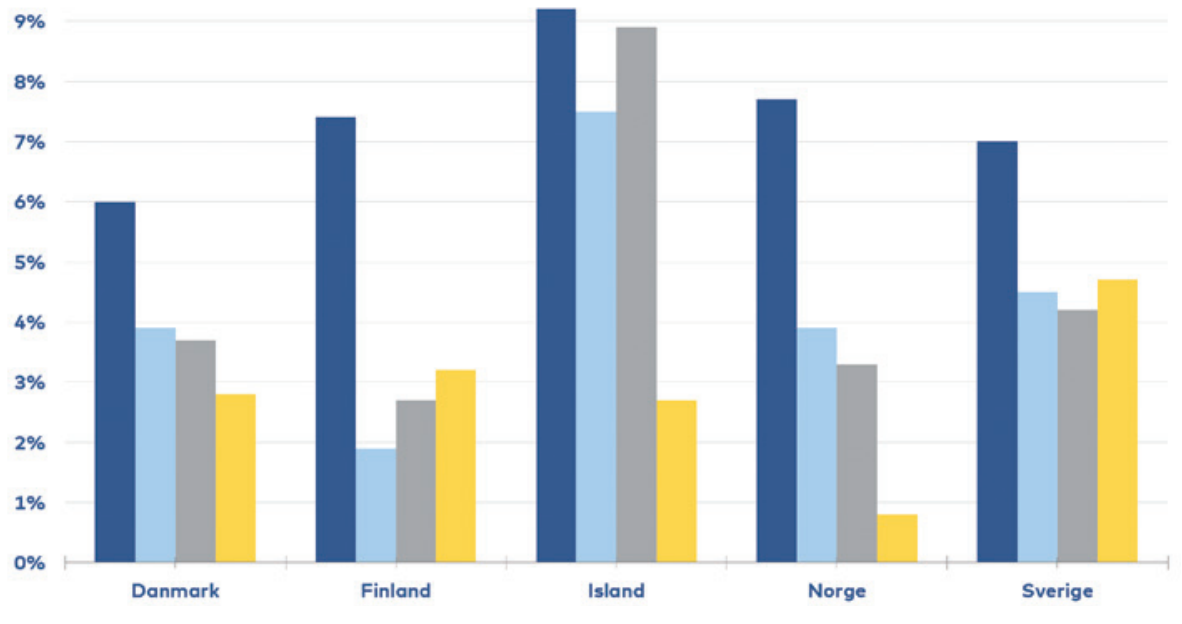

$10 \%$

$9 \%$

$8 \%$

$7 \%$

$6 \%$

$5 \%$

$4 \%$

$3 \%$

$2 \%$

$1 \%$

$0 \%$

$\%$

$\%$

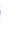

$\%$

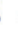

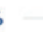

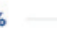

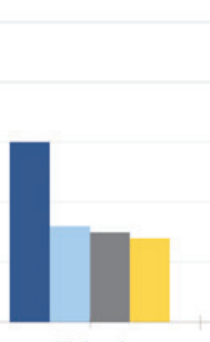

Finland

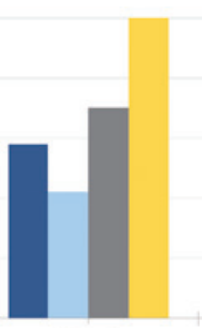

Island

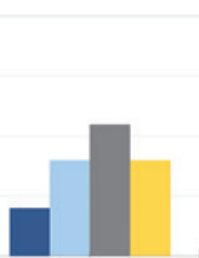

Norge

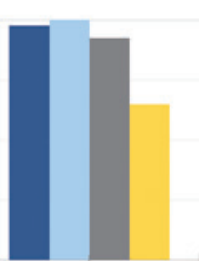

Sverige
Figur 6

Kvinder: Andel som ofte eller hele tiden føler sig deprimeret (fordelt på land og alder), 20122016

Kilde: The Happiness Research Institute på baggrund af data fra European Social Survey.

- 15-23

24-39

40-59

$60+$

Figur 7

Mænd: Andel som ofte eller hele tiden føler sig deprimeret (fordelt på land og alder), 20122016

Kilde: The Happiness Research Institute på baggrund af data fra European Social Survey.

- 15-23

24-39

40-59

$60+$ 


\section{Arbejdsløse er mere udsatte for mistrivsel og ulykke, især blandt mænd}

Næst efter dårlig generel sundhed, dårlig psykisk sundhed og indkomstulighed følger arbejdsløshed som den mest afgørende livsomstændighed for ulykke i de nordiske lande. Størstedelen af de nordiske befolkninger bruger det meste af deres liv på at arbejde. Det er derfor ikke tilfældigt, at beskæftigelse spiller så stor en rolle for det enkelte menneskes trivsel, hvilket også er en af de mest robuste kendsgerninger i lykkeforskning generelt. ${ }^{26}$

Langvarig ledighed er forbundet med stor ulykke, som er svær at tilpasse sig. Hvis en person er arbejdsløs over en længere periode, så forbliver hans/hendes trivselsniveau lavt, selv efter personen kommer i beskæftigelse. Trivslen bliver varigt mærket af erfaringen med arbejdsløshed. ${ }^{27}$

En del af forklaringen på, hvorfor arbejdsløse mistrives, kan tilskrives et dårligt psykisk helbred. Arbejdsløshed er forbundet med stress, og selvom beskæftigelse ikke nødvendigvis er en garanti for at blive stressfri, så er der særligt store sundhedsproblemer relateret til gruppen af arbejdsløse.

Langvarig arbejdsløshed er forbundet med stor ulykke. Hver tredje, der ufrivilligt er uden arbejde, trives ikke i de nordiske lande.
Mænd rammes hårdere end kvinder af arbejdsløshed.
Det fremgår af figur 8, at uligheden i trivsel mellem beskæftigede og arbejdsløse (især de kronisk syge og handikappede) i Norden er markant. Figuren viser, at arbejdsløse oftere er ulykkelige på tværs af alle nordiske lande. Det er kun overgået af mennesker med kroniske sygdomme og handicap. 12,8 procent af arbejdsløse falder inden for kategorien ulykkelige, mens 19,6 procent falder inden for kategorien mistrivsel. Det er altså næsten hver tredje uden job, som ikke trives i de nordiske lande.

Blandt beskæftigede er tallene 2,2 procent for ulykke og 6,8 procent for mistrivsel, hvilket i alt giver 9 procent, som ikke trives. Der er flere end tre gange så mange, der ikke trives eller er ulykkelige blandt arbejdsløse, i forhold til de beskæftigede.

Vi har i denne rapport gennemført en analyse, hvor vi tester sandsynligheden for at opleve depressive symptomer ved arbejdsløshed i sammenligning med beskæftigelse. Resultatet viser, at sandsynligheden er størst i Norge, hvor risikoen for depressive symptomer er mere end dobbelt så stor for arbejdsløse som for beskæftigede. Generelt rammes mænd hårdere end kvinder (se appendiks 3).

\section{Ulighed i social kontakt går værst ud over ældre mænd}

At have stærke relationer og et aktivt socialt liv fremhæves ofte som en af de vigtigste faktorer for menneskers liv og trivsel. I denne analyse har det ikke været muligt at teste på ufrivillig ensomhed, som vi ellers forventer er særligt udslagsgivende for uligheden i trivslen. I stedet har vi testet effekten af, at man enten aldrig eller sjældent mødes med venner, familie og kollegaer i sammenligning med, at man modsat har meget social kontakt med sin omgang- 


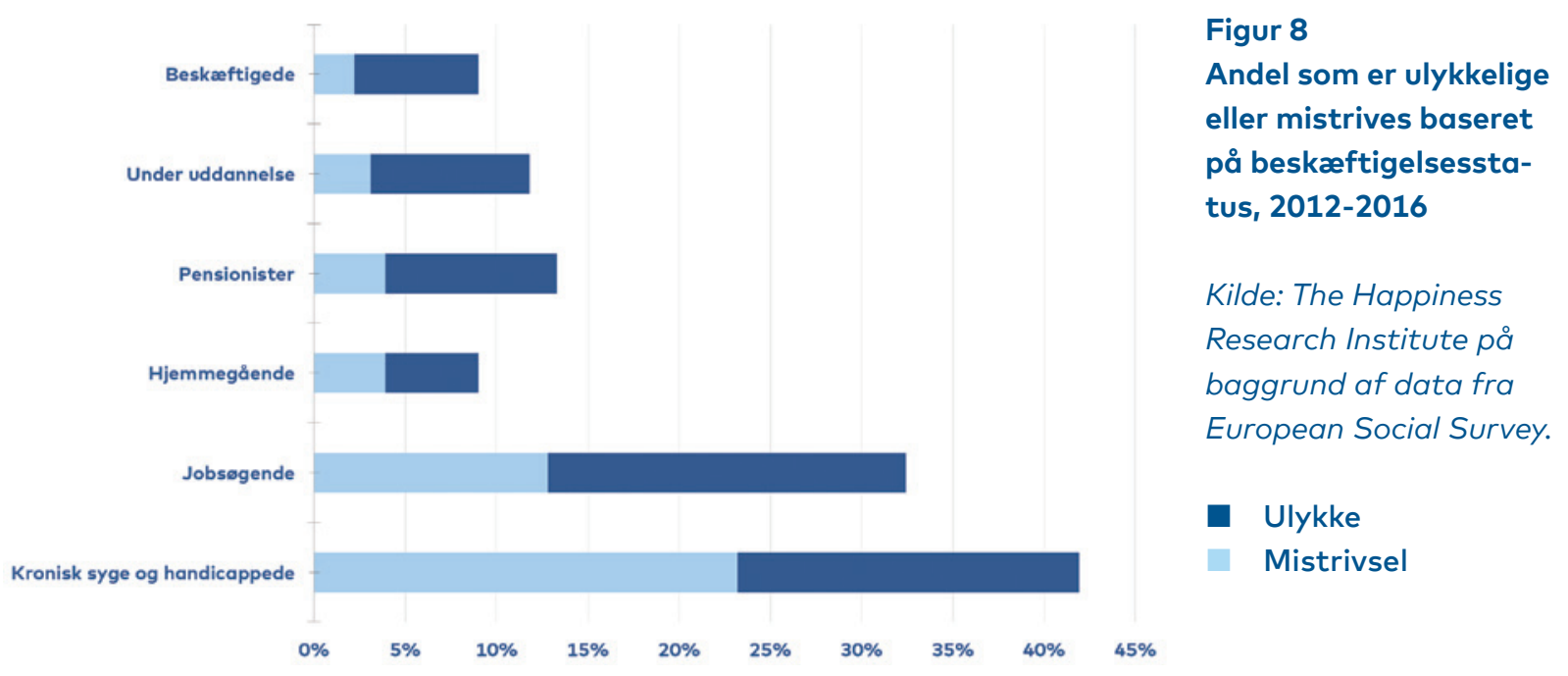


Mænd er mindre socialt aktive end kvinder. Eldre mænd har mindst social kontakt.

Meget religiøse mennesker er væsentligt lykkeligere end ikke-religiøse. skreds. I samtlige lande kan vi se en betydelig effekt af, at mennesker der mødes med venner, familie og kollegaer, trives markant bedre end mennesker, der aldrig eller sjældent gør.

Uligheden i social kontakt er også interessant i forhold til alder og køn, som illustreret i figur 9. Der findes en meget klar sammenhæng mellem alder og mangel på social kontakt, forstået på den måde, at ældre mennesker sjældnere har kontakt med deres omgangskreds end unge. Mest iøjenfaldende er dog den systematisk store kønsforskel, hvor mænd er mindre socialt aktive end kvinder, hvilket gælder på stort set alle alderstrin. ÆEldre mænd har mindst social kontakt, og det viser sig i form af en øget mistrivsel i netop denne gruppe.

\section{Lykke og religiøsitet}

Analysen viser, at religiøsitet - altså hvor troende man er - har en betydning for trivsel og trivselsuligheden. Selvom religiøsitet ikke er en top-5 faktor i forklaringen af mistrivsel og ulykke, har den en signifikant betydning i alle de nordiske lande.

Det er dog vigtigt at påpege, hvordan dette hænger sammen: Effekten fra religiøsitet på trivsel opstår kun, når personer er meget religiøse. Er man blot en anelse troende eller moderat religiøs, er der ingen trivselsforskelle at spore. Hvis man derimod scorer højest på en religiøsitetsskala, så er man også tilbøjelig til at være væsentligt mere lykkelig end den ikke-religiøse andel af befolkningen.

Denne effekt består, selv når vi har kontrolleret for alle de andre demografiske variabler og livsomstændigheder i modellen. Et par relevante bud på, hvorfor meget troende trives bedre, kunne være, at disse mennesker finder en større mening med tilværelsen gennem deres religion (svarende til den eudaimoniske lykke omtalt i indledningen), eller at religionen fungerer som en trøst eller et værn mod modgang i livet. Man kunne også overveje, om meget religiøse mennesker oplever en større tilknytning til et fællesskab - gennem kirken, synagogen eller moskéen - end det er tilfældet for den gennemsnitlige borger. 


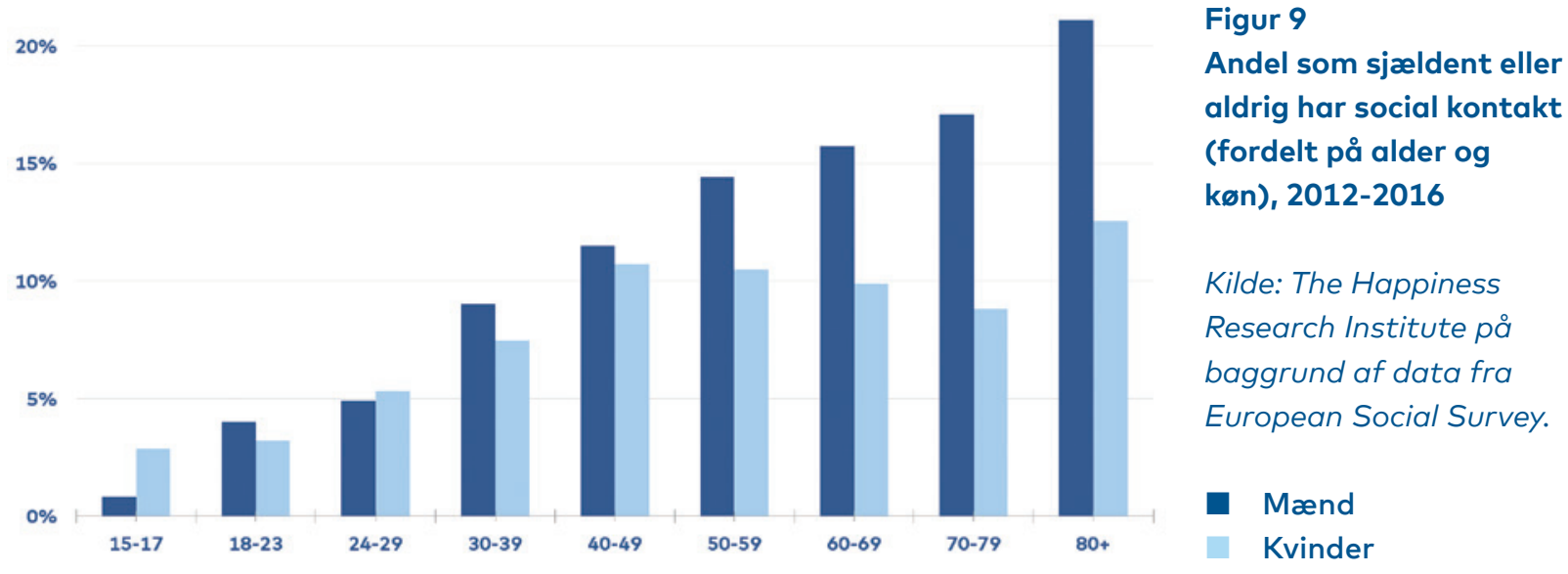


I forlængelse af sammenhængen mellem fysisk sundhed og trivsel, som vi berørte i forrige kapitel, viser et amerikansk studie for eksempel, at personer med kroniske sygdomme, som samtidig mistrives eller er ulykkelige, har 64 procent større risiko for at blive diagnosticeret med én eller flere følgesygdomme inden for et år, sammenlignet med kronisk syge personer som trives. Dette får konsekvenser for samfundsøkonomien blandt andet ved et øget forbrug af offentlige sundhedsydelser. ${ }^{30}$

Når vi taler om samfundsomkostninger, er dårlig psykisk sundhed et af de største trivselsrelaterede problemer. I Danmark estimeres det for eksempel, at de direkte og indirekte omkostninger løber op i 55 milliarder DKK om året, ${ }^{31}$ og samlet for OECD-lande vurderes det, at dårlig psykisk sundhed reducerer bruttonationalproduktet med 5 procent. ${ }^{32}$

\section{Ulykken udfordrer tilliden}

Tillid er en af hjørnestenene i de nordiske samfund: Folk i Norden rapporterer væsentlig højere tillidsniveaver end i resten af verden, og tilliden er afgørende for samfundets sammenhængskraft og synes også at have en væsentlig positiv effekt på vores samfundsøkonomi. ${ }^{33}$

Det er dog ikke en naturlov, at vi stoler på hinanden. Hvis vi skal sikre os et sammenhængende samfund i fremtiden, er det nødvendigt, at vi forholder os til de faktorer, som skaber og udfordrer tilliden.

Tidligere er indkomstulighed blevet set som en afgørende faktor for mistillid i samfundet, men nyere studier viser, at effekten fra trivselsulighed er væsentligt større. ${ }^{34}$ Det betyder, at en stigning i mistrivsel og ulykke i samfundet alt andet lige vil medføre til et fald i tillid.

Der findes ydermere en interessant sammenhæng mellem tillid og trivsel. Et studie viser for eksempel, hvordan mennesker, som bliver arbejdsløse, syge eller udsat for diskrimination, oftest vil opleve et væsentligt dyk i deres trivsel, men at dette dyk er størst i samfund med lav tillid og mindst i samfund med høj tillid. ${ }^{35}$ De høje tillidsniveauer i de nordiske lande fungerer derfor som et værn mod ulykke.

Disse sammenhænge taler således for et større politisk fokus på at skabe rammer, som bidrager til at folk trives. Ikke alene vil det gøre gavn for de mennesker, der er berørt af ulykke samt deres pårørende, det vil også have positive samfundsøkonomiske effekter og sikre, at vi kan bevare tilliden og sammenhængskraften i samfundet.
Blandt personer med kroniske sygdomme har det vist sig, at hvis de samtidig mistrives, øges risikoen for at få følgesygdomme.

Nyere studier viser, at effekten af trivselsulighed udfordrer tilliden i samfundet.

\footnotetext{
30 Rath, T \& Harter, J (2010): The Economics of Well-being, Gallup

31 Det Nationale Forskningscenter for Arbejdsmiljø (2010): Hvidbog om mentalt helbred, sygefravær og tilbagevenden til arbejde

32 The Global Happiness Council (2018): Global Happiness Policy Report

33 Nordisk Ministerråd (2017): Tillid - Det Nordiske Guld

34 Goff, L, J F Helliwell, and G Mayraz (2016): The Welfare Costs of Well-Being Inequality

35

Helliwell, J F, H Huang, and S Wang (2016): New Results on Trust and Well-Being
} 


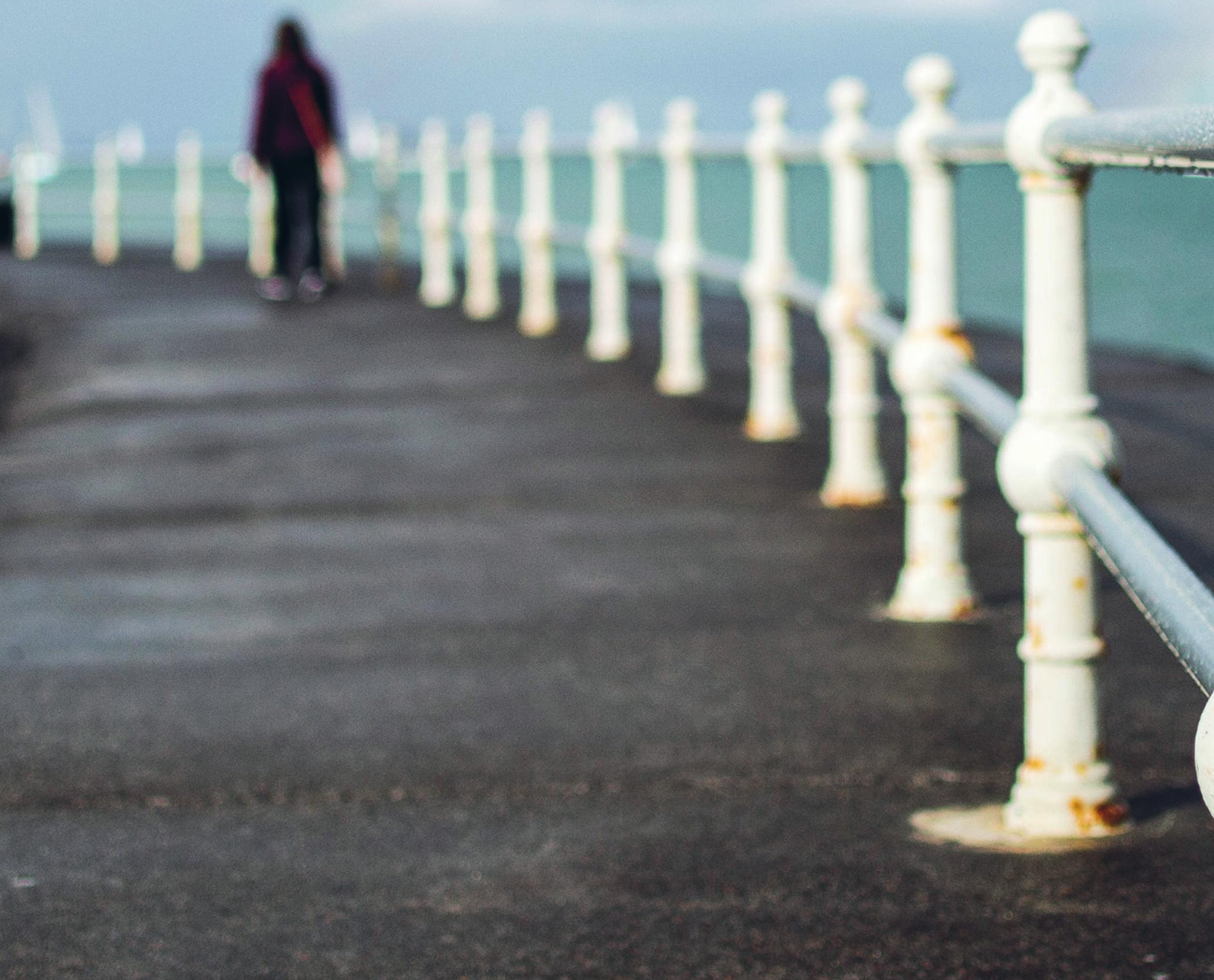




\section{Nordisk perspektiv}

Rapporten tegner samlet set et billede af Norden som en region, der står over for en række trivselsudfordringer. Det er en utopi at forestille sig et samfund, hvor ulykke og mistrivsel slet ikke eksisterer - og det er givetvis heller ikke ønskeligt. Livets måde at udfolde sig på vil for mange medføre perioder, hvor man ikke opfatter sig selv som lykkelig.

Årsagerne til ulykke og mistrivsel er unikke, men sammenfald og ligheder i analyseresultaterne på tværs af de nordiske lande indikerer dog, at visse generelle strukturer i samfundene påvirker trivslen negativt.

Det er ambitionen, at denne rapport med sit nordiske perspektiv kan bidrage til en debat om, hvordan vi begrænser antallet af mennesker, som oplever ulykke og mistrivsel.

Et essentielt spørgsmål er, hvad der kan gøres her og nu for at hjælpe de enkelte individer.Der rejser sig også et spørgsmål om, hvad den offentlige sektors og civilsamfundets rolle bør være i forhold til at løse problemet på et strukturelt plan.

At finde løsningerne på disse udfordringer kalder imidlertid på mere forskning og mere robuste datagrundlag om menneskers trivsel i Norden og de omstændigheder, der præger den. For eksempel kunne et datasæt dykke ned i trivselsvariationerne mellem kommuner, hvilket vil kunne give viden om, hvilke strukturer som medvirker til trivselsuligheden.

Derudover giver det god mening at anvende tidsseriedata - hvor man måler menneskers trivsel over tid - hermed kan man producere ny viden om, hvad der forårsager uligheder i trivsel og konsekvenserne af dette.

Det er vigtigt, at disse data åbnes for et bredere forskningsmiljø, så vi kan få forskellige perspektiver på, hvad der skaber bedst mulige liv for flest mulige mennesker.

For at lære mest muligt om problemet, og hvordan det bedst tackles, bør de nordiske lande dele mest mulig viden og erfaring om problemstillingen.
Årsagerne til ulykke er unikke for hvert enkelt individ, men generelle strukturer i samfundet kan også påvirke trivslen negativt.

De nordiske lande bør dele viden og erfaringer om problemstillingen. 


\section{Litteraturliste}

- Danmarks Statistik (2017): Ulighedsmål: Gini-koefficient.

- Det Nationale Forskningscenter for Arbejdsmiljø (2010): Hvidbog om mentalt helbred, sygefravær og tilbagevenden til arbejde, København: Det Nationale Forskningscenter for Arbejdsmiljø.

- European Social Survey. Data anvendt til generel analyse i undersøgelsen. Data hentet via: www.europeansocialsurvey.com

Specifikke kilder for data:

- European Social Survey Cumulative File, ESS 1-7 (2016). Data file edition 1.0. NSD Norwegian Centre for Research Data, Norway - Data Archive and distributor of ESS data for ESS ERIC.

- European Social Survey Round 8: European Social Survey Round 8 Data (2016). Data file edition 1.0. NSD - Norwegian Centre for Research Data, Norway - Data Archive and distributor of ESS data for ESS ERIC.

- Folkhälsomyndigheten (2016): Statistik över vuxnas psykiska hälsa, tilgået via: www.folkhalsomyndigheten.se/livsvillkor-levnadsvanor/psykisk-halsa-och-suicidprevention/statistik-psykisk-halsa/vuxnas-psykiska-halsa

- Gallup (tilgået april, 2018): Understanding How Gallup uses the Cantril Scale, tilgået via: http:// news.gallup.com/poll/122453/understanding-gallup-uses-cantril-scale.aspx Global

- Happiness Council (2018): Global Happiness Policy, United Arab Emirates: World Government Summit.

- Goff, L., Helliwell, J. \& Mayraz, G. (2016): The Welfare Costs of Well-Being Inequality, NBER Working Paper no. 21900.

- Happiness Research Institute \& Leo Innovation Lab (2017): World Psoriasis Happiness Report, Copenhagen.
- Helliwell, J. F., Huang, H., \& Wang, S. (2016): New Results on Trust and Well-Being, NBER Working Paper no. 22450.

- Helliwell, J., Layard, R., \& Sachs, J. (2015): World Happiness Report 2015, New York: Sustainable Development Solutions Network.

- Helliwell, J., Layard, R., \& Sachs, J. (2016): World Happiness Report 2016, New York: Sustainable Development Solutions Network.

- Helliwell, J., Layard, R., \& Sachs, J. (2017): World Happiness Report 2017, New York: Sustainable Development Solutions Network.

- Helliwell, J., Layard, R., \& Sachs, J. (2018): World Happiness Report 2018, New York: Sustainable Development Solutions Network.

- Nordisk Samarbejde (tilgået maj, 2018): Forventet Levealder, tilgået via: www.norden.org/da/tema/tidligere-temaer/ tema-2012/nordisk-statistik-i-50-aar-1/statistik-fra-1962-2012/forventet-levealder

- Nordic Council of Ministers, Nordic Centre for Welfare and Social Issues (2016): Mental health among youth in Finland: Who is responsible? What is being done?

- Nordic Council of Ministers, Nordic Council of Ministers Secretariat (2018): State of the Nordic Region 2018, Copenhagen: Nordic Council of Ministers

- Nordisk Ministerråd (2017): Tillid - Det Nordiske Guld.

- OECD (2013): Guidelines On Measuring Subjective Well-being, Paris: OECD Publishing.

- OECD (2017): Better Life Index, tilgået via: www.oecdbetterlifeindex.org

- OECD (2017): Better Life Initiative - Measuring Well-being and progress, Paris: OECD Statistics Directorate. 
- Rath, T., \& Harter, J. (2010): The Economics of Well-being, Gallup Consulting.

- Reneflot, A., Aarø, L.E., Aase, H., Reichborn-Kjennerud, T., Tambs, K., \& Øverland, S. (2018): Psykisk Helse i Norge.

- SDU (2017): Den Nationale Sundhedsprofil, data hentet via: www.danskernessundhed.dk

- Social Progress Imperative (2017): Social Progress Index, tilgået via: www.socialprogressimperative.org

- Steptoe, A., \& Wardle, J. (2011): Positive affect measured using ecological momentary assessment and survival in older men and women, Proceedings of the National Academy of Sciences.

- Statens Institut for Folkesundhed (2007): Folkesundhedsrapporten.

- Sundhedsdatastyrelsen (2017): Medicinforbrug - Indblik.

- The Happiness Research Institute (2013): Der er et lykkeligt land.

- UN NEWS (2012): Ban: new economic paradigm needed, including social and environmental progress, tilgået via: https://news.un.org/en/ story/2012/04/407782

- What Works Well-Being (2017): Measuring Well-Being Inequalities: A How-To Guide.

- World Health Organization (2017): Depression and Other Common Mental Disorders, Geneva.

- World Health Organization (2017): Scaling-up treatment of depression and anxiety: a global return on investment analysis. 


\section{Appendiks 1: Metode}

\section{Definition af trivselsulighed}

Der findes to anerkendte ${ }^{35}$ måder at måle trivselsulighed på:

- Standardafvigelse måler hvor stor afstanden er fra individerne i en gruppe til gruppens gennemsnit. Des større standardafvigelse, desto større spredning i gruppen og dermed mere ulighed. Man udregner standardafvigelsen ved at tage kvadratroden af den gennemsnitlige forskel mellem individuelle og gennemsnittet opløftet i anden potens.

- $\quad$ Proportioner man opdeler trivslen i grupper med for eksempel lav, middel og høj trivsel, og undersøger dernæst, hvilke kendetegn personer i hver gruppe har tilfælles med hinanden, og hvilke kendetegn de forskellige grupper ikke har tilfælles. På den måde kan man for eksempel finde unikke kendetegn ved personer med lav trivsel, som dermed er særligt gældende for den gruppe og siger noget om, hvilken type personer der oplever lav trivsel.

Vi har anvendt proportionsmålet i denne rapport. Vi har opdelt hvert lands befolkninger i 3 grupper, inspireret af Gallup. ${ }^{36}$

1. Ulykke - Personer med en subjektiv trivsel på $0-4$

2. Mistrivsel - Personer med en subjektiv trivsel på 5-6

3. Trivsel - Personer med en subjektiv trivsel på 7-10

\section{Data}

Vi anvender et datasæt fra European Social Survey (ESS). Vores dataudtræk indeholder de fem nordiske lande (samt Storbritannien til sammenligning) for perioden 2012-2016. Dataindsamlingen er foregået hvert andet år, så vores dataudtræk strækker sig over tre indsamlingsrunder, hvor ud af hhv. Danmark og Island kun har deltaget $\mathrm{i}$ to (DK mangler i 2016, og IS mangler i 2014). Alle respondenter er over 15 år gamle.

En central antagelse for alle vores udregninger præsenteret i rapporten er dermed, at vi med rimelighed kan sammenligne befolkningerne i et givet land i år 2012 med ditto i år 2016, dvs. der er ikke sket væsentlige forskelle i de Nordiske lande i denne periode. Da vi kan se, at den gennemsnitlige trivsel er aftagende i alle landende, mens trivselsuligheden er tiltagende i alle landene, kan man sige, at vores resultater er konservative. Tog man et øjebliksbillede i 2016, ville uligheden være større, end hvad vi rapporterer.

Årsagen til, at vi alligevel gør os denne antagelse, er, at vores undersøgelsesdesign kræver relativt store datamængder, som vi kun kan opnå ved at aggregere over flere indsamlingsrunder (specielt i Island som har færre respondenter i hver indsamlingsrunde). Se tabel 5.

Da vi kun har kunnet indsamle data fra de fem ovenstående lande, er vi afgrænset fra at forholde os til både Færøerne, Grønland og Åland.

\section{Et konservativt estimat for mistrivsel}

Estimaterne for mistrivsel i denne analyse afviger en anelse fra andet tilgængelige data. Analyserne i denne rapport baseres på European Social Survey, da vi her har mulighed for at sammenligne de nordiske lande med hinanden. Hvis vi derimod benytter andet data med tilsvarende trivselstematikker, får vi et noget andet billede: Danmarks Statistik gennemførte for eksempel et livskvalitetsstudie i $2015^{37}$ på den danske befolkning, som viste, at 5,3 procent rapporterede meget lave livskvalitetstal (mellem 0 og 3). I European Social Survey er det kun 
Tabel 5

Stikprøvestørrelse for hvert land

\begin{tabular}{|l|c|c|c|c|}
\hline & 2012 & 2014 & 2016 & Samlet \\
\hline Danmark & 1.648 & 1.500 & Ingen tilgængelig data & 3.148 \\
\hline Finland & 2.194 & 2.085 & 1.923 & 6.202 \\
\hline Island & 748 & Ingen tilgængelig data & 878 & 1.626 \\
\hline Norge & 1.622 & 1.433 & 1.543 & 4.598 \\
\hline Sverige & 1.844 & 1.788 & 1.543 & 5.175 \\
\hline
\end{tabular}

1,9 procent af den danske befolkning, som falder inden for denne kategori. Denne forskel kan muligvis tilskrives indsamlingsmetoder.

På baggrund af disse forskelle anbefaler vi, at alle tal i denne rapport læses og fortolkes som konservative estimater, og vi understreger, at det er meget muligt, at mistrivslen er mere udbredt end hvad tallene beretter.
For Danmark er det i øvrigt vigtigt at bemærke, at det seneste data er fra 2014. Da der i flere nationale målinger over de senere år ses en udvikling med stigende stress og dårligere psykisk sundhed i befolkningen, er der således også god grund til at forvente, at mistrivselstallene for dette land er højere i dag end i 2014, hvorfor problemet er større, end tallene her i rapporten afslører. 


\section{Appendiks 2: Analyse}

\section{A. Forhold mellem vækst i BNP pr. indbygger (PPP) og vækst i lykke}

Tabel 6 på side 38 illustrerer netop, hvor lidt selv en stor vækst i BNP betyder for væksten i lykkeniveauet for mennesker i den nogle af verdens rigeste lande - inklusiv de nordiske - hvis det er det eneste værktøj, vi benytter os af. For at løfte lykkeniveauet med 5 procent i for eksempel Norge, skal man helt op på en vækst i BNP per indbygger PPP på 70 procent. Det er altså nærmest utænkeligt, at man kan løfte lykkeniveauet i Norge eller de andre nordiske lande blot en lille smule ved alene at fokusere på økonomisk vækst målt i BNP.

\section{B. Oversigt over testvariabler i regressionsmodellen}

I en regressionsanalyse har vi udvalgt en række vafhængige variable, som kan forklare, hvorfor folk rapporterer ulykke og mistrivsel (den afhængige variabel).

I denne regressionsanalyse inkluderer vi almindelige demografiske variable i vores analyse såsom køn og alder. Derudover ønsker vi at teste områder, som vi ved, er relevante specifikt for trivsel og lykke såsom social kontakt, psykisk sundhed, fysisk sundhed, beskæftigelsesstatus m.fl.

- Alder

- Køn

- Uddannelsesbaggrund

- Indkomst

- Civilstatus

- Domicil (om man bor i storby, på landet, i en landsby osv.)

- Dårlig psykisk sundhed (spørgsmålet er relateret til hvor ofte man føler sig deprimeret)

- Dårlig generel sundhed (spørgsmålet er en selvvurdering af generelt helbred)

- Arbejdsløs

- Indkomstulighed

- Religiøsitet (spørgsmålet er relateret til hvor religiøs man er, vanfægtet hvilken religion man er tilknyttet)
- Begrænset social kontakt (spørgsmål er relateret til hvor ofte man er i kontakt med venner, familie og kollegaer. Ingen kontakt kan ikke nødvendigvis oversættet til ufrivillig ensomhed)

- Immigrant/Født i landet

- Etnisk majoritet/Etnisk minoritet

\section{Analysedesign}

\section{Regneeksempel fra "hele Norden"}

Vi estimerer følgende lineære regression:

$$
y_{i}=x_{i}^{T} \beta+\varepsilon_{i}
$$

Hvor xi er variablerne vi estimerer og beta er deres respektive koefficienter. Epsilon angiver usikkerheden i vores regressionsmodel. I denne regression er yi trivslen på en almindelig 0-10 skala.

Intententionen bag modellen er, at vi forsøger at estimere de variabler, xi som bedst muligt kan forklare personers trivsel, yi. Det er her vigtigt at pointere, at vi ud fra denne metode kun kan tale om statistiske sammenhænge, dvs. korrelation og ikke kausalitet. Vi kan dermed ikke sige, at personer f.eks. svarer $y=10$ fordi $x=5$, men kun at de to værdier ofte findes hos samme personer. Der er altså en korrelation mellem de to variabler, men vi kender ikke kausalitetsforholdet.

På side 39-40 findes alle resultaterne for hele Norden, men udregninger er de samme for alle landene.

De tre kolonner angiver tre forskellige regressioner, som vi estimerer. I den første, fuld skala, indeholder den afhængige variabel, yi alle svarmuligheder på en trivselsskala fra 0 til 10. I den anden, mistrivsel, indeholder den afhængige variabel, yi kun to svarmuligheder, hhv. 0 og 1, fordi vi har defineret, at alle dem, der har svaret fra 0 til 6 er i mistrivsel, mens alle fra 7 til 10 er i ikke-mistrivsel. I den tredje, ulyk$k e$ ", indeholder den afhængige variabel, yi også kun to svarmuligheder, hhv. 0 og 1. Her har vi defineret, at alle dem, der har svaret fra 0 til 4 er ulykkelige, mens alle fra 5 til 10 er ikke-ulykkelige. 
Dermed har vi opdelt vores datasæt i tre proportioner, som beskrevet ovenfor. Ved at sammenligne for eksempel ulykke med fuld skala får vi et overblik over de faktorer, der kan give os indsigter $i$, hvilke typer personer, der mistrives. Hvis koefficienten for en given variabel er signifikant i fuld skala-regressionen, men ikke i for eksempel ulykke-regressionen, så betyder det, at pågældende variabel - selvom den har en entydig sammenhæng med den gennemsnitlige persons lykke - ikke har en entydig sammenhæng med ulykkelige personer. Et godt eksempel er variablen indkomst. Her finder vi en tydelig sammenhæng med, at des højere indkomst personer har, desto mere lykkelige er de også, i hvert fald i forhold til den gennemsnitlige person på den fulde skala. Men vi finder ikke, at indkomst har nogen entydig sammenhæng med ulykkelige personer - med undtagelsen værende de rigeste 10 procent, som lader til at være mindre ulykkelige (NB. Indkomstgrupperne er opdelt efter deciler, så gruppe 10 svarer til de rigeste 10 procent).

Hvor meget mindre ulykkelige de rigeste 10 procent er, er til gengæld lidt sværere at sige noget konkret om. Det skyldes, at alle vores variabler er kategoriske, og dermed er vores koefficienter ikke udtrykt i procenter. Dog kan vi godt rangere, hvilke variabler der kan forklare mest ud fra størrelsen af deres koefficienter. I Norden er det dermed deprimeret - ofte, der bedst forklarer, hvilke personer der er ulykkelige. Et resultat der næsten giver sig selv, men ikke desto mindre bør tages alvorligt.
Man kan desværre ikke sammenligne koefficienterne mellem de forskellige regressioner. Det skyldes at antallet af personer, der er ulykkelige ikke er det samme som antallet af personer, der er i mistrivsel. Da der er færrest personer, som er ulykkelige, er koefficienterne også mindst for den regression.

Alle variablerne, vi arbejder med, er såkaldt kategoriske variable. Dvs. de indeholder forskellige kategorier som for eksempel variablen social, der indeholder fem svarmuligheder:

1. Aldrig

2. Månedligt

3. Ugentligt

4. Flere gange om ugen

5. Dagligt

I dette tilfælde findes førstnævnte ikke i vores output for hele Norden nedenfor. Det skyldes, at den første svarmulighed i hver variabel bruges som et benchmark, dvs. til at sammenligne de øvrige variabler med.

Vi tester for multikollinaritet - dvs. for korrelationer mellem to eller flere vafhængige variabler - ved at udregne den såkaldte "Variance Inflation Factor". Oftest vil man acceptere vif-værdier under fire mellem vafhængige variabler. I vores regressioner har vi ingen problemer med multikollinaritet. 
Tabel 6

\begin{tabular}{|c|c|c|c|}
\hline & $\begin{array}{l}\text { Nuværende BNP per } \\
\text { indbygger ( } 1.000 \text { US } \$ \text { ) }\end{array}$ & $\begin{array}{l}\text { BNP per indbygger hvis } \\
\text { livskvalitet skal løftes } \\
\text { med } 5 \text { procent (US } \$ \text { ) }\end{array}$ & $\begin{array}{l}\text { Procent løft i BNP } \\
\text { per indbygger hvis } \\
\text { livskvaliteten skal } \\
\text { løftes med } 5 \text { procent }\end{array}$ \\
\hline Danmark & 49,6 & 84,2 & $70 \%$ \\
\hline Finland & 44,0 & 75,8 & $72 \%$ \\
\hline Island & 52,1 & 87,8 & $68 \%$ \\
\hline Norge & 70,6 & 119,7 & $70 \%$ \\
\hline Sverige & 51,3 & 85,2 & $66 \%$ \\
\hline Cameroun & 3,4 & 4,8 & $41 \%$ \\
\hline Guatemala & 8,2 & 12,7 & $55 \%$ \\
\hline Storbritannien & 43,6 & 71,6 & $64 \%$ \\
\hline Tyskland & 50,2 & 82,2 & $64 \%$ \\
\hline USA & 59,5 & 96,8 & $63 \%$ \\
\hline
\end{tabular}




\section{Resultater for hele Norden}

\begin{tabular}{|c|c|c|c|}
\hline Variabler & Fuld skala & Mistrivsel & Ulykke \\
\hline Skæringspunkt & $\begin{array}{l}7,91^{\star * *} \\
(0,10)\end{array}$ & $\begin{array}{l}2,07^{\star \star \star} \\
(0,43)\end{array}$ & $\begin{array}{l}2,88^{\star \star *} \\
(0,69)\end{array}$ \\
\hline Køn & $\begin{array}{l}0,08^{\star *} \\
(0,02)\end{array}$ & $\begin{array}{l}0,08 \\
(0,12)\end{array}$ & $\begin{array}{l}0,17 \\
(0,20)\end{array}$ \\
\hline Beskæftigelse - uddannelse & $\begin{array}{l}0,25^{\star \star \star} \\
(0,04)\end{array}$ & $\begin{array}{l}0,26 \\
(0,21)\end{array}$ & $\begin{array}{l}0,45 \\
(0,41)\end{array}$ \\
\hline Beskæftigelse - arbejdsløs jobsøgende & $\begin{array}{l}-0,68^{\star \star \star} \\
(0,07)\end{array}$ & $\begin{array}{l}-0,98^{\star \star \star} \\
(0,25)\end{array}$ & $\begin{array}{l}-1,14^{\star \star} \\
(0,36)\end{array}$ \\
\hline Beskæftigelse - arbejdsløs ikke-jobsøgende & $\begin{array}{l}-0,77^{\star \star \star} \\
(0,12)\end{array}$ & $\begin{array}{l}-0,95^{\star} \\
(0,41)\end{array}$ & $\begin{array}{l}-0,81 \\
(0,59)\end{array}$ \\
\hline Beskæftigelse - permanent syg / handikappet & $\begin{array}{l}-0,25^{\star \star} \\
(0,08)\end{array}$ & $\begin{array}{l}-0,24 \\
(0,28)\end{array}$ & $\begin{array}{l}-0,57 \\
(0,36)\end{array}$ \\
\hline Beskæftigelse - pensioneret & $\begin{array}{l}0,37^{\star * *} \\
(0,03)\end{array}$ & $\begin{array}{l}0,42^{*} \\
(0,16)\end{array}$ & $\begin{array}{l}0,23 \\
(0,28)\end{array}$ \\
\hline Beskæftigelse - militær & $\begin{array}{l}0,08 \\
(0,36)\end{array}$ & $\begin{array}{l}0,66 \\
(1,98)\end{array}$ & $\begin{array}{l}-1,00 \\
(2,00)\end{array}$ \\
\hline Beskæftigelse - hjemmegående & $\begin{array}{l}0,23^{* \star \star} \\
(0,07)\end{array}$ & $\begin{array}{l}0,30 \\
(0,33)\end{array}$ & $\begin{array}{l}-0,38 \\
(0,48)\end{array}$ \\
\hline Beskæftigelse - andet & $\begin{array}{l}0,11 \\
(0,13)\end{array}$ & $\begin{array}{l}0,29 \\
(0,59) \\
\end{array}$ & $\begin{array}{l}0,63 \\
(1,08)\end{array}$ \\
\hline Partner & $\begin{array}{l}-0,34^{\star \star \star} \\
(0,03)\end{array}$ & $\begin{array}{l}-0,46^{\star * *} \\
(0,14)\end{array}$ & $\begin{array}{l}-0,26 \\
(0,23)\end{array}$ \\
\hline Indkomstgruppe - 2 & $\begin{array}{l}-0,05 \\
(0,06)\end{array}$ & $\begin{array}{l}0,04 \\
(0,22)\end{array}$ & $\begin{array}{l}-0,12 \\
(0,33)\end{array}$ \\
\hline Indkomstgruppe - 3 & $\begin{array}{l}0,08 \\
(0,06)\end{array}$ & $\begin{array}{l}0,07 \\
(0,23)\end{array}$ & $\begin{array}{l}0,06 \\
(0,36)\end{array}$ \\
\hline Indkomstgruppe -4 & $\begin{array}{l}0,17^{\star *} \\
(0,06)\end{array}$ & $\begin{array}{l}0,27 \\
(0,24)\end{array}$ & $\begin{array}{l}0,29 \\
(0,39)\end{array}$ \\
\hline Indkomstgruppe - 5 & $\begin{array}{l}0,15^{*} \\
(0,06)\end{array}$ & $\begin{array}{l}0,23 \\
(0,25)\end{array}$ & $\begin{array}{l}0,30 \\
(0,42)\end{array}$ \\
\hline Indkomstgruppe - 6 & $\begin{array}{l}0,23^{* * *} \\
(0,06)\end{array}$ & $\begin{array}{l}0,70^{* *} \\
(0,27)\end{array}$ & $\begin{array}{l}0,70 \\
(0,45)\end{array}$ \\
\hline Indkomstgruppe - 7 & $\begin{array}{l}0,28^{\star \star *} \\
(0,06)\end{array}$ & $\begin{array}{l}0,64^{\star} \\
(0,28)\end{array}$ & $\begin{array}{l}0,72 \\
(0,48)\end{array}$ \\
\hline Indkomstgruppe - 8 & $\begin{array}{l}0,26^{\star \star \star} \\
(0,06)\end{array}$ & $\begin{array}{l}0,60^{*} \\
(0,27)\end{array}$ & $\begin{array}{l}0,92 \\
(0,50)\end{array}$ \\
\hline Indkomstgruppe - 9 & $\begin{array}{l}0,28^{\star \star \star} \\
(0,06)\end{array}$ & $\begin{array}{l}1,02^{\star \star} \\
(0,31)\end{array}$ & $\begin{array}{l}0,95 \\
(0,57)\end{array}$ \\
\hline Indkomstgruppe - 10 & $\begin{array}{l}0,39 * \star * \\
(0,06)\end{array}$ & $\begin{array}{l}1,16^{\star \star \star} \\
(0,31)\end{array}$ & $\begin{array}{l}1,15^{\star} \\
(0,57)\end{array}$ \\
\hline Etnicitet & $\begin{array}{l}0,15^{\star} \\
(0,07)\end{array}$ & $\begin{array}{l}0,29 \\
(0,28)\end{array}$ & $\begin{array}{l}0,49 \\
(0,44)\end{array}$ \\
\hline
\end{tabular}




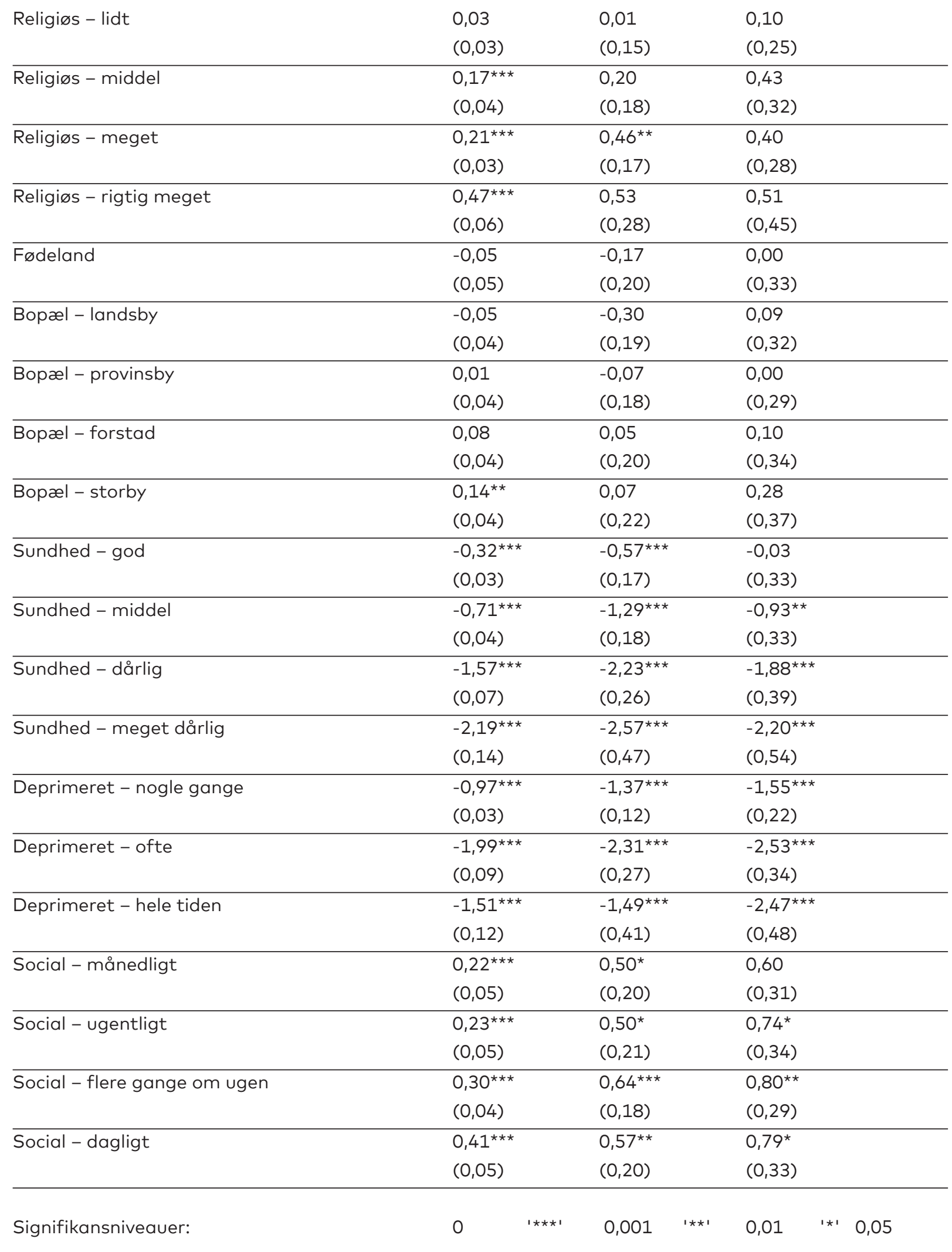




\section{Appendiks 3: Sandsynligheden for depressive symptomer ved arbejdsløshed}

- Danmark: 1,7 gange større sandsynlighed for at være deprimeret ved arbejdsløshed

- Finland: 1,4 gange større sandsynlighed for at være deprimeret ved arbejdsløshed

- Norge: 2,2 gange større sandsynlighed for at være deprimeret ved arbejdsløshed

- Sverige: 1,7 gange større sandsynlighed for at være deprimeret ved arbejdsløshed.

*Data for arbejdsløse islændinge ikke tilstrækkelig stor til at gennemfore forudsigelse på mental sundhed.

Generelt i denne rapport finder vi, at dårlig mental sundhed ofte rammer kvinder. Men i forholdet mellem beskæftigelse og depression, er det mændene, som er mest udsatte.

Sandsynligheden for depressive symptomer ved arbejdsløshed (fordelt på køn)

- Kvinder: 1,5 gange større sandsynlighed for at være deprimeret ved arbejdsløshed

- Mænd: 1,9 gange større sandsynlighed for at være deprimeret ved arbejdsløshed.

Kilde: The Happiness Research Institute baseret på data fra European Social Survey. 




\section{Nordisk Ministerråd}

Nordens Hus

Ved Stranden 18

DK-1061 København K

www.norden.org

Det er ganske vist rigtigt, at vi i Norden er lykkeligere end i andre, men det findes også dem i Danmark, Finland, Island, Norge og Sverige, der giver udtryk for mistrivsel, eller sågar at de er ulykkelige, når de beskriver deres liv.

Rapporten undersøger hvilke faktorer der har størst betydning for, hvorfor nogle mennesker i Norden er lykkelige, mens andre mistrives eller er ulykkelige. Studiet kortlægger også, hvem der oftest rammes af mistrivsel og ulykke. Afslutningsvis diskuteres mulige konsekvenser for vores samfund. 